Check for updates

Cite this: RSC Adv., 2017, 7, 51640

Received 24th July 2017

Accepted 18th October 2017

DOI: 10.1039/c7ra08149a

rsc.li/rsc-advances

\section{Synthesis and biological evaluation of 1-(2- (adamantane-1-yl)-1H-indol-5-yl)-3-substituted urea/thiourea derivatives as anticancer agents $\uparrow$}

\author{
Hongyu Hu, $\dot{t}^{\mathrm{ab}}$ Chunrong Lin, $\dot{t}^{\mathrm{a}}$ Mingtao Ao, $\dot{t}^{\mathrm{a}}$ Yufen Ji, ${ }^{\mathrm{a}}$ Bowen Tang, ${ }^{a}$ \\ Xiaoxiao Zhou, ${ }^{a}$ Meijuan Fang, (DD *a Jinzhang Zeng ${ }^{\star a}$ and Zhen $\mathrm{Wu}^{\star a}$
}

\begin{abstract}
The indole ring, adamantane, and urea groups are important components of bioactive molecules. The orphan nuclear receptor Nur77 as a unique transcription factor encoded by an immediate early gene is a potential therapeutic target for cancer treatment. We synthesized a series of 1-(2-(adamantane-1-yl)$1 \mathrm{H}$-indol-5-yl)-3-substituted urea/thiourea derivatives and identified which of these potential anticancer candidates could modulate the expression and activity of Nur77. The synthesized compounds were initially evaluated for their anti-proliferative activity against H460 lung cancer cells, HepG2 liver cancer cells, and MCF-7 breast cancer cells. Major compounds were found to be active against these tested cancer cell lines. The compounds with $\mathrm{IC}_{50}$ values down to $20 \mu \mathrm{M}$ exhibited selective cytotoxicity effects on the human lung cancer cell line ( $\mathrm{H} 460)$ and the normal lung cell line (MCR-5). Compounds 7n, 7s, and $7 \mathrm{w}$ induced Nur77-expression in a time- and dose-dependent manner in H460 cells. Compounds $7 \mathrm{n}$ and $7 \mathrm{~s}$ strongly induced Parp cleavage in $\mathrm{H} 460$ cells, but $7 \mathrm{w}$ resulted in a slight induction of apoptosis. The apoptotic effect of 7s was largely inhibited when the Nur77 was knocked down by shRNA. This indicated that Nur77 served as a critical mediator for the anticancer action of 7s. The molecular docking study between Nur77 and 7s revealed that compound 7s exhibited a promising binding affinity with Nur77. These findings will provide a direction for the developing Nur77 regulator as anticancer agents.
\end{abstract}

\section{Introduction}

Nur77 (also known as NR4A1, NGFI-B, or TR3) is an orphan member of the nuclear receptor super-family that regulates the expression of genes involved in multiple physiological and pathological processes. ${ }^{1}$ As an immediate-early response gene, Nur77 expression could be induced by various stimuli, including mitogenic and apoptotic signaling. ${ }^{2-4}$ Nur77 plays a role in cell survival, cell death, and is implicated in various malignancies. ${ }^{3-11}$ Nur77 is upregulated in gastric tumorsphere cells, ${ }^{12}$ non-small cell lung cancer (NSCLC) tissues and cells, ${ }^{13}$ and colon tumors. ${ }^{\mathbf{1 4 1 5}}$ Previous studies have found that Nur77 is often overexpressed in tumour tissues, when compared to the para-carcinoma normal tissues. ${ }^{\mathbf{1 6}}$ Nur77 is a potentially promising drug target for cancer treatment. A number of anticancer compounds with diverse chemical structures, such as

\footnotetext{
${ }^{a}$ Fujian Provincial Key Laboratory of Innovative Drug Target Research, School of Pharmaceutical Sciences, Xiamen University, South Xiang-An Road, Xiamen, 361102, China. E-mail: wuzhen@xmu.edu.cn; jzzeng@xmu.edu.cn; fangmj@xmu. edu.cn; Fax: +86-592-2189868; Tel: +86-592-2189868

${ }^{b}$ College of Xingzhi, Zhejiang Normal University, Jinhua 321004, China

$\dagger$ Electronic supplementary information (ESI) available. See DOI: 10.1039/c7ra08149a

\$ The first two authors are co-first authors.
}

acetylshikonin analogue $\mathrm{SK} 07,{ }^{17}$ DIM-C-pPhOCH $3,{ }^{18}$ Vit $\mathrm{K} 2,{ }^{19}$ diindolylmethane analog, ${ }^{20} \mathrm{Csn}-\mathrm{B},{ }^{21}$ cardenolides $\mathrm{H} 9$ and ATEi2-b4, ${ }^{22}$ AmB-NC, ${ }^{23}$ CD437, ${ }^{10,24} n$-butylidenephthalide, ${ }^{25}$ and norcantharidin ${ }^{26}$ have been identified as critical modulators of the genomic or the nongenomic pathways of Nur77. These findings suggest that Nur77 is a critical and meaningful drug target. Thus, we are interested in exploring a novel Nur77 regulator.

The indole ring has been proven to be a critical pharmacophore in many chemotherapeutics. ${ }^{27-29}$ The introduction of different side chains around the indole nucleus has resulted in the development of various therapeutic drugs, including obatoclax, ${ }^{30}$ and sunitinib,,$^{31}$ as well as many lead compounds that boast a wide variety of biological activities. Modifying the $2^{\text {nd }}$ and $5^{\text {th }}$ positions of the indole moiety has been shown to be crucial for receptor binding and activation. ${ }^{32}$ The adamantane derivatives were initially used as an antiviral drug (adamantane) to combat various strains of the flu, ${ }^{33}$ to treat parkinson's disease (adapalene, dopamantine, memantine, rimantadine and tromantadine), and as dipeptidyl peptidase-4 (DPP-4) inhibitors (saxagliptin, and vildagliptin) for the treatment of type 2 diabetes. ${ }^{34}$ Some other clinical drugs like sorafenib are urea derivatives of the indole pharmacophore.

Based on the biological profiles of the indole ring, the adamantane, the urea group, and the continuation of our research 
work on synthesis of indole derivatives, ${ }^{32}$ we initially synthesized a series of novel 1-(2-(adamantan-1-yl)-1 $H$-indol-5-yl)-3substituted urea/thiourea derivatives and evaluated their anticancer activity on cancer cell line (HepG2), and breast cancer cell line (MCF-7) by MTT assay. The compounds that exhibited prominent activity against tested cancer cell lines with $\mathrm{IC}_{50}$ down to $20 \mu \mathrm{M}$ were subsequently tested for their cytotoxicity on normal cell lines (MCR-5 and LO2) as well as their effect on Nur77 activation in $\mathrm{H} 460$ cells. Those compounds that had Nur77 activation ability in $\mathrm{H} 460$ cells and also exhibited selective cytotoxicity on tumours and normal cell lines which were isolated from the same tissue, were used to further explore their induction of apoptosis in various tumour cell lines and normal NIH-3T3 cells. Compounds $\mathbf{7 s ,} \mathbf{7 n}$ and $\mathbf{7 w}$ induced apoptosis in H460 cells. This ability for apoptosis induction was closely associated with their Nur77 activation. The RNA interference technology and the molecular docking study were performed to explore the molecular mechanisms that mediate the induction of apoptosis by this specific class of compounds.

\section{Results and discussion}

\subsection{Syntheses of the designed compounds}

The general chemistry for the synthesis of $7 \mathbf{a}-7 \mathbf{y}$ and $9 \mathbf{9}-\mathbf{9 0}$ is outlined in Scheme 1. First, we synthesized 2-adamantane- $1 H^{-}$ indol-5-amine (5). The treatment of 1-adamantanecarboxylic acid chloride (1) with $o$-toluidine resulted in $\mathrm{N}$ - $\mathrm{O}$-tolylcycloadamantanecarboxamide (2), ${ }^{32}$ and $2.5 \mathrm{M}$ of $n$-butyl lithium in hexane was then added dropwise to obtain the corresponding 2adamantane- $1 H$-indole (3). ${ }^{32}$ Compound 5 was formed through the nitrification and catalytic hydrogenation of compound $3 .^{35}$ 5-Isocyanato- $1 H$-indole-adamantane $(6)$ was obtained by reacting compound 5 with triphosgene. ${ }^{36}$ The intermediate 6 was subjected to reactions with various amines in order to produce compounds $7 \mathbf{a}-7 \mathbf{y}$. The reaction of compound $\mathbf{5}$ with triethylenediamine (Dabco), $\mathrm{CS}_{2}$, and bis(trichloromethyl)carbonate (BTC) resulted in 5-isothiocyanato- $1 H$-indole-adamantane (8). ${ }^{37}$ Compound $\mathbf{8}$ was converted into compounds $9 \mathbf{9}-\mathbf{9 0}$ by treatment with the corresponding amine. The structures of the target compounds were confirmed with ${ }^{1} \mathrm{H}-\mathrm{NMR},{ }^{13} \mathrm{C}-\mathrm{NMR}$, and high-resolution mass spectrometry (HRMS). The purities of the target compounds were evaluated with high-performance liquid chromatography with diode-array detection (HPLC-DAD) performed at $254 \mathrm{~nm}$ and $280 \mathrm{~nm}$.

\subsection{Anti-proliferative activities of synthesized compounds in various cancer cells and their structure-activity relationship}

The synthesized compounds were evaluated for their antiproliferative activities against various human cancer cell lines including H460, HepG2 and MCF-7. The concentration required for $50 \%$ inhibition of cell viability $\left(\mathrm{IC}_{50}\right)$ was calculated. The $\mathrm{IC}_{50}$ values of the compounds are summarized in Tables 1 and 2 . The results indicated that a majority of the synthesized compounds had a moderate anti-proliferative activity against the three human cancer cell lines. Exceptions were found in compounds 7c, 7d, 7e, 7g, 7h, 7i, 9c, and 9d. Attempts were made to establish the structure-activity relationship (SAR) among the tested compounds based on data collected from three independent experiments.

2.2.1. 1-(2-(Adamantan-1-yl)-1H-indol-5-yl)-3-substituted urea derivatives. Among the alkyl substituted compounds (7a$7 \mathbf{j}$ ), compound $7 \mathbf{f}$ with a phenethyl group and 7a with a $t$-butyl group had the highest potency of anti-proliferative properties in $\mathrm{H} 460$ cells $\left(\mathrm{IC}_{50}\right.$ of $\left.7 \mathbf{f}, 0.42 \pm 0.09 \mu \mathrm{M}\right)$, HepG2 cells $\left(\mathrm{IC}_{50}\right.$ of $7 \mathbf{f}$, $0.28 \pm 0.08 \mu \mathrm{M})$ and MCF-7 cells $\left(\mathrm{IC}_{50}\right.$ of $\left.7 \mathrm{a}, 5.16 \pm 0.20 \mu \mathrm{M}\right)$. The $\mathrm{IC}_{50}$ values of compounds $\mathbf{7 c}, \mathbf{7 d}, \mathbf{7 g}$, and $\mathbf{7 h}$ were over 100 $\mu \mathrm{M}$ for at least one of the three tested human cancer cell lines. This indicated that the introduction of a $n$-alkyl group that had more than three carbon atoms to the pharmaceutical core was unfavourable for anti-proliferative properties. Compound 7e which contained a cycloheptyl group had no activity with $\mathrm{IC}_{50}$ values up to $100 \mu \mathrm{M}$. Compound $7 \mathbf{b}$ which had a cyclobutyl group demonstrated good anti-proliferative activity $\left(\mathrm{IC}_{50}, 10.0\right.$ $25.0 \mu \mathrm{M}$ ). This suggested that the substitution of the cycolakyl
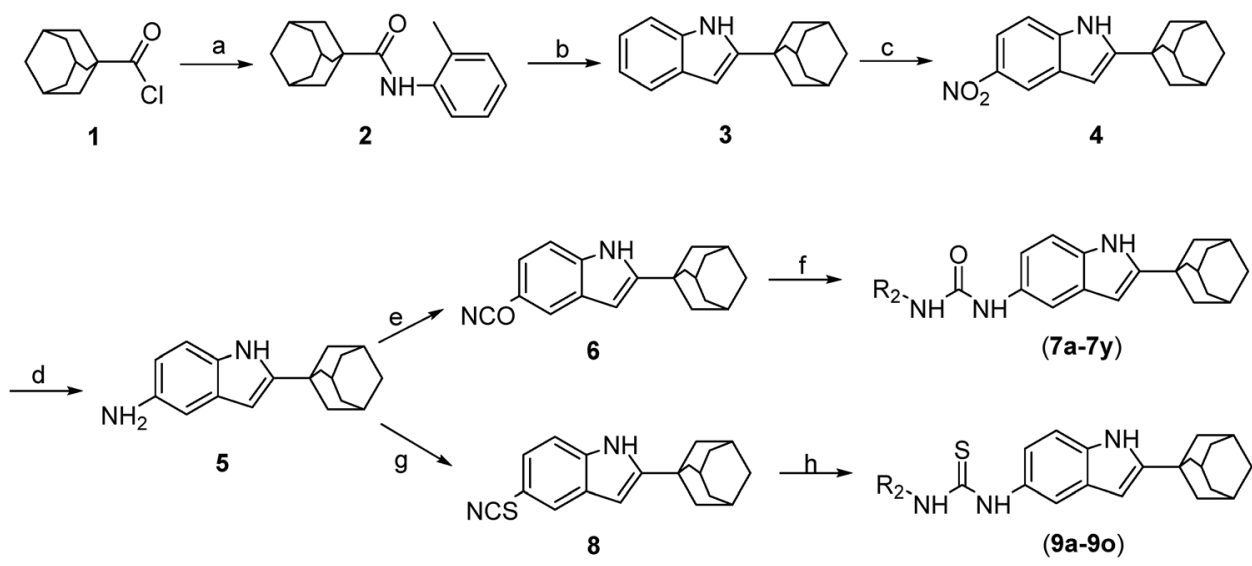

Scheme 1 Synthesis of 1-(2-(substituted hydrazinecarbonyl group)- $1 \mathrm{H}$-indol-5-yl)-3-substituted urea. Reagents and conditions: (a) toluene, $\mathrm{O}-$ toluidine, $\mathrm{K}_{2} \mathrm{CO}_{3}$, r.t., $4 \mathrm{~h}$; (b) $\mathrm{n}$-BuLi, THF, $0{ }^{\circ} \mathrm{C}, \mathrm{N}_{2}, 3$ h; (c) $\mathrm{NH}_{4} \mathrm{NO}_{3}, \mathrm{H}_{2} \mathrm{SO}_{4}, 0{ }^{\circ} \mathrm{C}, 1 \mathrm{~h}$; (d) $10 \% \mathrm{Pd} / \mathrm{C}, \mathrm{MeOH}, 70{ }^{\circ} \mathrm{C}, 2 \mathrm{~h}$. (e) Triphosgene, THF, trimethylamine, $0{ }^{\circ} \mathrm{C}, 4 \mathrm{~h}$; (f) $\mathrm{R}-\mathrm{NH}_{2}$, toluene, $60{ }^{\circ} \mathrm{C}, 4 \mathrm{~h}$. (g) Dabco, $\mathrm{CS}_{2}$, toluene, $\mathrm{BTC}, \mathrm{DCM}$. (h) $\mathrm{R}-\mathrm{NH}_{2}$, toluene, $60{ }^{\circ} \mathrm{C}, 4 \mathrm{~h}$. 
Table 1 Anti-proliferative activity of 1-(2-(adamantan-1-yl)-1H-indol-5-yl)-3-substituted urea 7a-7y ${ }^{a}$

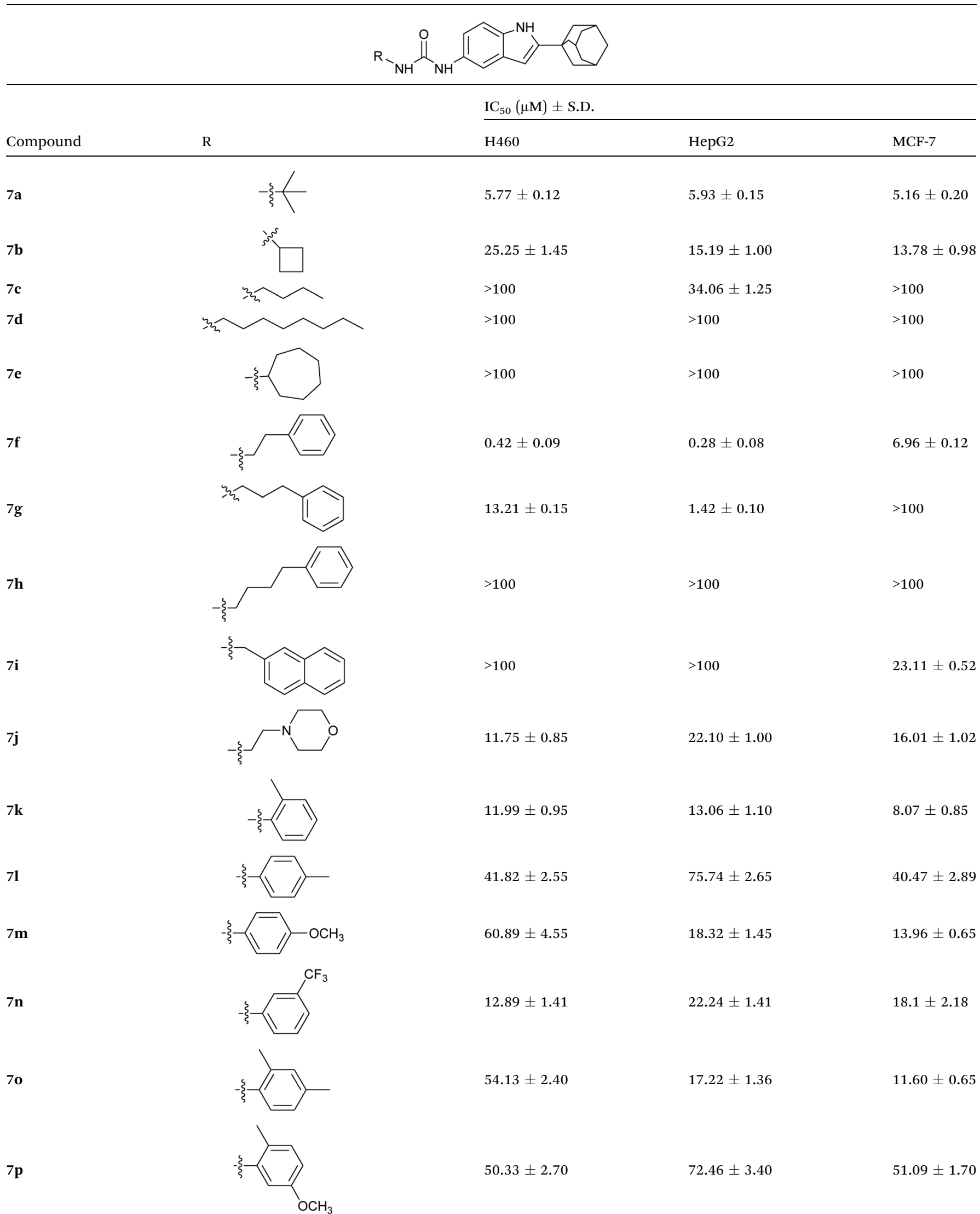




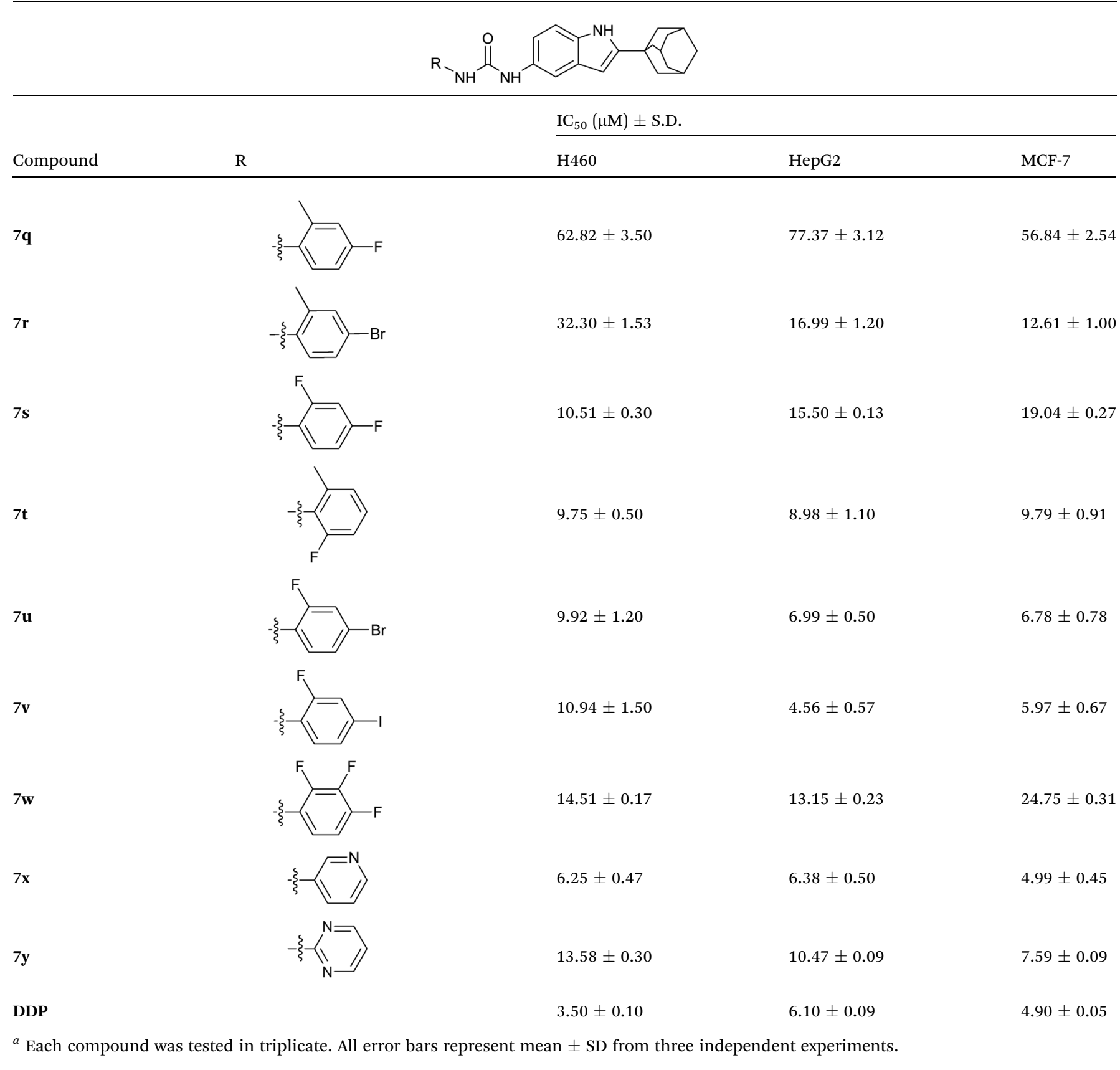

group, which had a small ring at the $N^{\prime}$-urea position, had a greater effect on the compound's anti-proliferative activity. We found that compounds $\mathbf{7} \mathbf{k}-\mathbf{7} \mathbf{w}$, which contained the aryl groups at the $N^{\prime}$-urea position, generally had good anti-proliferative properties. The impact of the substituent at the phenyl ring was investigated by introducing halogen $(\mathrm{F}, \mathrm{Br}$, or I), methyl $\left(\mathrm{CH}_{3}\right)$, trifluoromethyl $\left(\mathrm{CF}_{3}\right)$, and/or methoxy $\left(\mathrm{OCH}_{3}\right)$ groups. The results revealed that $p$-substitution at the phenyl ring might not be helpful for their anti-proliferative properties. Compound $\mathbf{7 k}$ had lower $\mathrm{IC}_{50}$ values than $7 \mathbf{l}$ or $\mathbf{7 0}$. Compound $\mathbf{7 t}$ had lower $\mathrm{IC}_{50}$ values than 7q. Compounds with $\mathrm{Br}(7 \mathbf{r}$ or $7 \mathbf{u})$ and $\mathrm{I}(7 \mathbf{v})$ at the $\mathrm{C}-4$ position of phenyl ring exhibited better inhibition against tested human cancer cell lines when compared with $7 \mathbf{q}$ or $7 \mathbf{s}$, where $\mathrm{F}$ was introduced at the C-4 position of phenyl ring, as shown in Table 1 . The remaining derivatives showed moderate activity. The presence of aromatic heterocyclic, such as pyridyl (7x) and pyrimidine (7y), at the urea end enhanced the anti-proliferative activity.

2.2.2. 1-(2-(Adamantan-1-yl)-1H-indol-5-yl)-3-substituted thiourea derivatives. We generated an additional series of thiourea derivatives with the functional group adamant (Ad) at the C2-position of the indole ring. This allowed us to explore the effect of the urea group on the cancer cells' proliferation. These thiourea derivatives were generally less active against H460, 
Table 2 Anti-proliferative activity $\left(\mathrm{IC}_{50}, \mu \mathrm{M}\right)$ of thiourea derivatives $9 \mathrm{a}-9 \mathrm{o}^{a}$

\begin{tabular}{|c|c|c|c|c|}
\hline & & \multicolumn{3}{|c|}{$\mathrm{IC}_{50}(\mu \mathrm{M}) \pm$ S.D. } \\
\hline Compound & $\mathrm{R}$ & $\mathrm{H} 460$ & HepG2 & MCF-7 \\
\hline $9 a$ & & $20.23 \pm 0.12$ & $15.93 \pm 0.17$ & $25.89 \pm 0.20$ \\
\hline $9 b$ & & $27.25 \pm 1.40$ & $18.02 \pm 1.00$ & $21.13 \pm 0.98$ \\
\hline $9 \mathrm{c}$ & & $>100$ & $>100$ & $>100$ \\
\hline 9d & & $>100$ & $>100$ & $>100$ \\
\hline $9 e$ & & $30.20 \pm 0.88$ & $35.50 \pm 0.85$ & $25.00 \pm 0.20$ \\
\hline 9f & & $14.52 \pm 0.10$ & $22.20 \pm 0.18$ & $16.96 \pm 0.17$ \\
\hline $9 \mathrm{~g}$ & & $25.36 \pm 0.15$ & $26.12 \pm 0.10$ & $19.62 \pm 0.10$ \\
\hline $9 h$ & & $22.23 \pm 0.18$ & $22.36 \pm 0.15$ & $26.36 \pm 0.19$ \\
\hline $9 \mathrm{i}$ & & $38.54 \pm 0.18$ & $32.56 \pm 0.25$ & $28.11 \pm 0.52$ \\
\hline 9j & & $31.80 \pm 0.85$ & $22.10 \pm 1.00$ & $26.01 \pm 1.00$ \\
\hline 9k & & $25.19 \pm 0.95$ & $29.06 \pm 1.10$ & $18.07 \pm 0.85$ \\
\hline 91 & & $21.80 \pm 1.55$ & $15.74 \pm 0.65$ & $20.47 \pm 1.89$ \\
\hline $9 m$ & & $25.80 \pm 1.55$ & $28.48 \pm 1.45$ & $23.80 \pm 0.65$ \\
\hline $9 n$ & & $41.89 \pm 1.20$ & $22.20 \pm 1.40$ & $28.1 \pm 2.10$ \\
\hline 90 & & $20.13 \pm 1.40$ & $17.22 \pm 1.30$ & $21.60 \pm 0.60$ \\
\hline DDP & & $3.50 \pm 0.10$ & $6.10 \pm 0.09$ & $4.90 \pm 0.05$ \\
\hline
\end{tabular}

${ }^{a}$ Each compound was tested in triplicate. All error bars represent mean \pm SD from three independent experiments. 
HepG2 and MCF-7 cells than the urea derivatives (Table 2). Among the thiourea derivatives, compound 9 f had the highest anti-proliferative activity against $\mathrm{H} 460$ cells $(14.52 \pm 0.10 \mu \mathrm{M})$ and MCF-7 cells (16.96 $\pm 0.17 \mu \mathrm{M})$. Compound 9a had the highest cellular anti-proliferative activity against HepG2 cells (15.93 $\pm 0.17 \mu \mathrm{M})$. Both displayed lower growth inhibition

Table 3 In vitro cytotoxicity of urea derivatives on normal cells ${ }^{a}$

\begin{tabular}{|c|c|c|c|c|}
\hline \multirow[b]{2}{*}{ Compound } & \multicolumn{2}{|l|}{ MRC-5 } & \multicolumn{2}{|l|}{$\mathrm{LO} 2$} \\
\hline & $\begin{array}{l}\mathrm{IC}_{50}(\mu \mathrm{M}) \\
\pm \text { S.D. }\end{array}$ & $\mathrm{RTI}^{b}$ & $\begin{array}{l}\mathrm{IC}_{50}(\mu \mathrm{M}) \\
\pm \text { S.D. }\end{array}$ & $\mathrm{RTI}^{c}$ \\
\hline $7 a$ & $77.37 \pm 0.07$ & 13.41 & $5.43 \pm 0.09$ & 0.92 \\
\hline $7 f$ & $>100$ & $>200$ & $5.52 \pm 0.04$ & 19.71 \\
\hline $7 \mathbf{j}$ & $68.25 \pm 0.11$ & 5.80 & $33.32 \pm 0.09$ & 1.51 \\
\hline $7 \mathbf{k}$ & $56.35 \pm 0.08$ & 4.70 & $7.71 \pm 0.07$ & 0.59 \\
\hline $7 n$ & $85.76 \pm 0.13$ & 6.65 & $13.95 \pm 0.14$ & 0.63 \\
\hline $7 s$ & $73.86 \pm 0.11$ & 7.03 & $3.44 \pm 0.10$ & 0.22 \\
\hline $7 t$ & $>100$ & $>10.26$ & $29.64 \pm 0.13$ & 3.30 \\
\hline $7 \mathbf{u}$ & $50.34 \pm 0.12$ & 5.07 & $5.12 \pm 0.09$ & 0.73 \\
\hline $7 v$ & $63.71 \pm 0.06$ & 5.82 & $14.73 \pm 0.07$ & 3.23 \\
\hline $7 w$ & $>100$ & $>6.89$ & $5.19 \pm 0.06$ & 0.39 \\
\hline $7 x$ & $46.38 \pm 0.09$ & 7.42 & $4.46 \pm 0.05$ & 0.71 \\
\hline $7 \mathbf{y}$ & $67.35 \pm 0.12$ & 5.96 & $7.64 \pm 0.05$ & 0.73 \\
\hline DDP & $>100$ & $>28.57$ & $39.69 \pm 0.16$ & 6.51 \\
\hline
\end{tabular}

${ }^{a}$ Each compound was tested in triplicate. All error bars represent mean \pm SD from three independent experiments. ${ }^{b}$ The $\mathrm{IC}_{50}$ ratio is between lung normal MRC-5 cells to cancer $\mathrm{H} 460$ cells. ${ }^{c}$ The $\mathrm{IC}_{50}$ ratio is between liver normal LO2 cells to cancer HepG2 cells. activity for the cancer cells when compared to compounds $7 f$ and $7 \mathbf{a}$ in the urea series. The follow-up studies focused on urea derivatives.

\subsection{In vitro cytotoxicity of urea derivatives against two normal cell lines}

Twelve urea derivatives that showed prominent activity within all three of the human cancer cell lines with $\mathrm{IC}_{50}$ values down to $20 \mu \mathrm{M}$ were assessed within the in vitro cytotoxic activity against the human normal lung MCR-5 cell line and the normal hepatocytes LO2 cell line. These urea derivatives' $\mathrm{IC}_{50}$ values for the MCR-5 cells were above $45.0 \mu \mathrm{M}$. They exhibited good antiproliferative activity against the $\mathrm{LO} 2$ cells with $\mathrm{IC}_{50}$ values (after $48 \mathrm{~h}$ of treatment) ranging from $4.0 \mu \mathrm{M}$ to $35.0 \mu \mathrm{M}$, as shown in Table 3. This demonstrated these compounds were less toxic for the MCR-5 cells than for the LO2 cells. The $\mathrm{IC}_{50}$ ratio of the normal cells to the cancer cells was termed the "relative toxicity index" (RTI). The RTI was estimated to investigate their sensitivity between the normal and the tumour cells in the two human tissue systems (lung and liver). In the lung system, the tested urea derivatives were sensitivity to cancer H460 cells, with RTI values up to 4.70. Most of the urea derivatives in the liver system showed lower selective between the human liver cancer HepG2 cells and the normal hepatocytes LO2 cell line ( $\mathrm{RTI}<2$ ). This excluded compounds $7 \mathbf{f}, 7 \mathbf{t}$ and $7 \mathbf{v}$. The results indicated that the normal lung MCR-5 cells were more resistant to the toxic activity of these compounds than the lung cancer H460 cells. A majority of the compounds did not

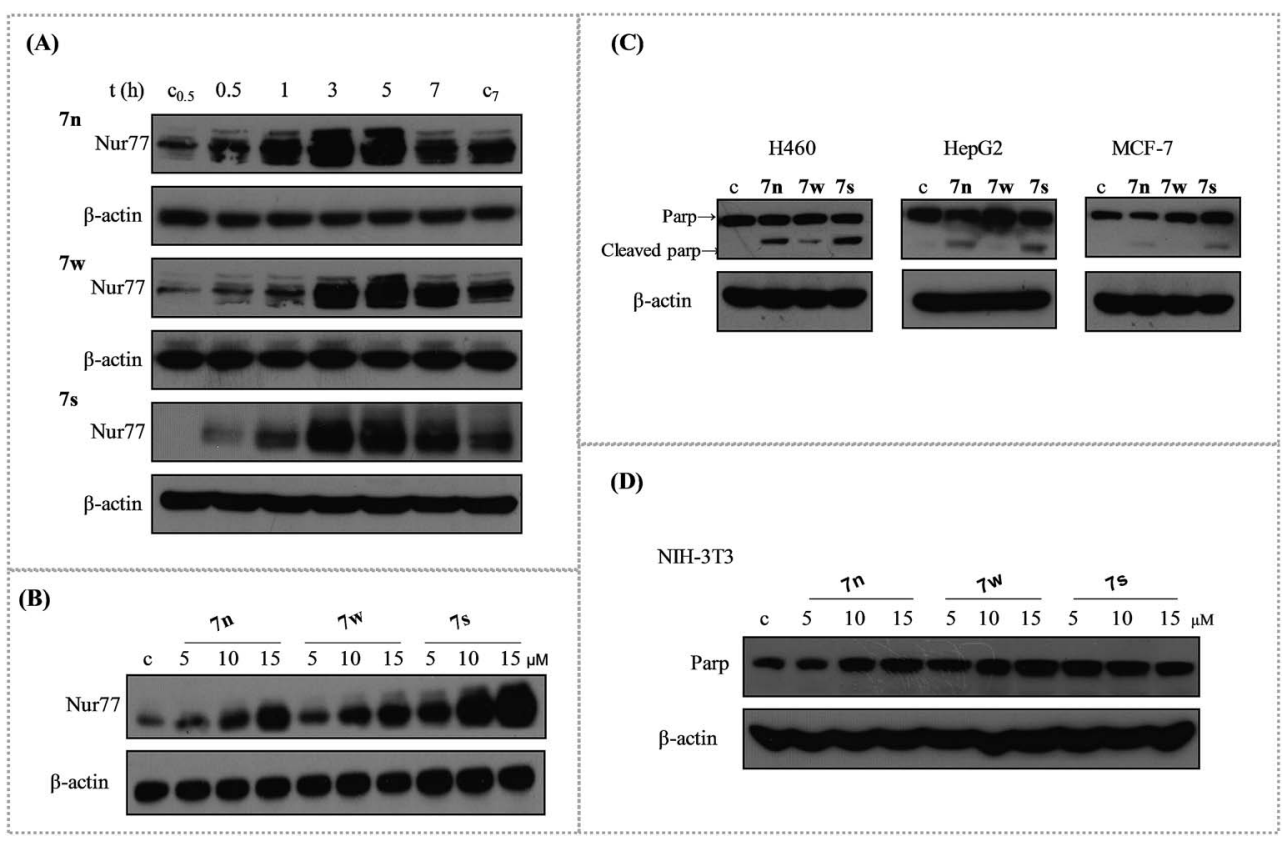

Fig. 1 The Nur77 activation of compounds 7n, 7w, and 7s in H460 cells and their apoptosis induction in H460, HepG2, MCF-7 and NIH-3T3. (A) Time-course analysis. $\mathrm{H} 460$ cancer cells treated with compounds $(10 \mu \mathrm{M})$ for $0.5 \mathrm{~h}, 1 \mathrm{~h}, 3 \mathrm{~h}, 5 \mathrm{~h}$, and $7 \mathrm{~h}$ were analysed to detect Nur77 levels via western blotting. (B) Dose dependent effect of compounds to active Nur77. H460 cancer cells treated with compounds (5 $\mu \mathrm{M}, 10 \mu \mathrm{M}$, and $15 \mu \mathrm{M}$ ) for $3 \mathrm{~h}$ were analysed via western blotting. (C) The apoptotic effects of compounds 7n, 7s, and 7w in H460, HepG2 and MCF-7 cancer cells. These three cancer cell lines were initially treated with $10 \mu \mathrm{M}$ compounds for $24 \mathrm{~h}$ and then analysed for the cleavage of Parp protein via western blotting. (D) The apoptotic effects of compounds in $\mathrm{NIH}-3 \mathrm{T3}$ cells. 
possess a selective resistance against the HepG2 cancer cells or the LO2 normal hepatocytes cells.

\subsection{The Nur77 activation ability of compounds with $\mathbf{I C}_{50}$ values below $20 \mu \mathrm{M}$ in $\mathrm{H} 460$}

A popular research model has showed that $\mathrm{H} 460$ cancer cells are sensitive to the Nur77 dependent apoptotic effect. ${ }^{\mathbf{1 0 4 0}}$ Our synthesized urea derivatives had a good sensitivity between the normal MCR-5 cells and the tumour H460 cells that were isolated from human lung tissue. So, we investigated whether our synthesized urea derivatives with $\mathrm{IC}_{50}$ values below $20 \mu \mathrm{M}$ could activate Nur77 in the $\mathrm{H} 460$ cancer cells. There were three compounds (7n, 7s, and $7 \mathbf{w}$ ) that activated Nur77. Results showed that Nur77 was activated upon treatment with $10 \mu \mathrm{M}$ of the compounds $(\mathbf{7 n}, \mathbf{7} \mathbf{s}$, and $\mathbf{7 w})$ in a time-dependent manner (Fig. 1(A)). Nur77 activation was observed in H460 cells treated with $7 \mathbf{n} / 7 \mathbf{s}$ for $0.5 \mathrm{~h}$. This activation was delayed for $1 \mathrm{~h}$ in compound $7 \mathbf{w}$. Nur77 was activated further when treated for $3 \mathrm{~h}$ and $5 \mathrm{~h}$ with any of the compounds. The activation was maintained at a high level at $7 \mathrm{~h}$. We examined whether Nur77 activation was also dose-dependent. H460 cancer cells were treated with various concentrations of each compound for $3 \mathrm{~h}$ (5 $\mu \mathrm{M}, 10 \mu \mathrm{M}$, and $15 \mu \mathrm{M}$ ) (Fig. 1(B)). As the concentration of each compound increased, the activation of Nur77 improved. Note, when equal amounts of protein lysates $(40 \mu \mathrm{g})$ was added, $7 \mathrm{~s}$ was more effective in up regulating Nur77 than $7 \mathbf{n}$ and $7 \mathbf{w}$. $7 \mathbf{w}$ was the weakest compound.

\subsection{The apoptosis induction of $7 \mathrm{n}, 7 \mathrm{w}$ and $7 \mathrm{~s}$ in $\mathbf{H 4 6 0}$, HepG2, MCF-7, and NIH-3T3}

Apoptosis is a popular approach used by a majority of the anticancer drugs to kill tumour cells. ${ }^{38}$ Apoptosis stimulation is considered standard and is the best strategy for anticancer therapy. ${ }^{39}$ Compounds $\mathbf{7 n}, 7 \mathbf{s}$, and $\mathbf{7 w}$ were selected to study the apoptotic effects in various human cancer cells. These cancer cell lines were treated with the three compounds at $10 \mu \mathrm{M}$ for $24 \mathrm{~h}$ to induce apoptosis. The cleavage of PARP protein was used as a sensitive apoptotic marker that occurred early in the apoptotic response. It was then examined by western blotting. The PARP cleavage was observed in various degrees in the tested cell lines (Fig. 1(C)). The induction of PARP cleavage of all three compounds was apparent in $\mathrm{H} 460$ cancer cells. Compounds $7 \mathbf{n}$ and $7 \mathbf{s}$ had better activity than $7 \mathbf{w}$. Compounds $7 \mathbf{n}$ and $7 \mathbf{s}$ induced the cleavage of PARP protein in HepG2 cancer cells, but $7 \mathbf{w}$ did not have an effect. Compound $7 \mathbf{s}$ was the only compound that slightly induced PARP cleavage in MCF-7 cancer cells. These results suggested that $\mathbf{7 n}, \mathbf{7 s}$, and $\mathbf{7 w}$ were more potent inducers of apoptosis in $\mathrm{H} 460$ cancer cell line than the other two cell lines. Compound 7s showed higher apoptosis against these three human cancer cell lines than compounds $7 \mathbf{w}$ and 7n. The apoptotic effect of these compounds at various concentrations was tested in NIH-3T3 mouse embryo cells over $24 \mathrm{~h}$. The results showed that all of the three compounds did not induce PARP cleavage at various concentrations for $24 \mathrm{~h}$ (Fig. 1(D)). This indicated that these three compounds had little effect on normal cells.

\subsection{Compound 7s induced apoptosis depending the Nur77} activation and the best growth inhibition of $\mathbf{H 4 6 0}$ cancer cells

We used RNA interference technology to confirm that the apoptosis effect of these compounds was related with the activation of Nur77. The H460 cancer cells were transfected with shNur77 or shctr for $24 \mathrm{~h}$ and then treated with $10 \mu \mathrm{M}$ of the compounds for an additional $24 \mathrm{~h}$. The cleavage of PARP and the expression of Nur77 were examined (Fig. 2(A)). The compounds still induced Parp cleavage in cells transfected with the shctr. In cells transfected with the shNur77, the Nur77 was effectively blocked. The degree of PARP cleavage of $7 \mathbf{s}$ and $\mathbf{7 n}$ was significantly down regulated, particularly in $7 \mathbf{s}$. There was little change for $7 \mathbf{w}$. This suggested that Nur77 could play a key role in the apoptosis effect of $7 \mathrm{~s}$ in $\mathrm{H} 460$ cells.

The cell growth inhibition of $\mathbf{7 n}, \mathbf{7 s}$, and $\mathbf{7 w}$ in $\mathrm{H} 460$ cancer cells was confirmed with MTT assays. The effects of these compounds on the growth of $\mathrm{H} 460$ cells at various concentrations ( $5 \mu \mathrm{M}, 10 \mu \mathrm{M}$, and $15 \mu \mathrm{M})$ were tested at $24 \mathrm{~h}, 48 \mathrm{~h}, 72 \mathrm{~h}$, and $96 \mathrm{~h}$ (Fig. 2(B)). The results showed that these compounds inhibited the proliferation of the $\mathrm{H} 460$ cell line in a dose- and time-dependent manner. Compound 7s demonstrated superior growth inhibition on $\mathrm{H} 460$ cells. At exposure times up to $96 \mathrm{~h}$,

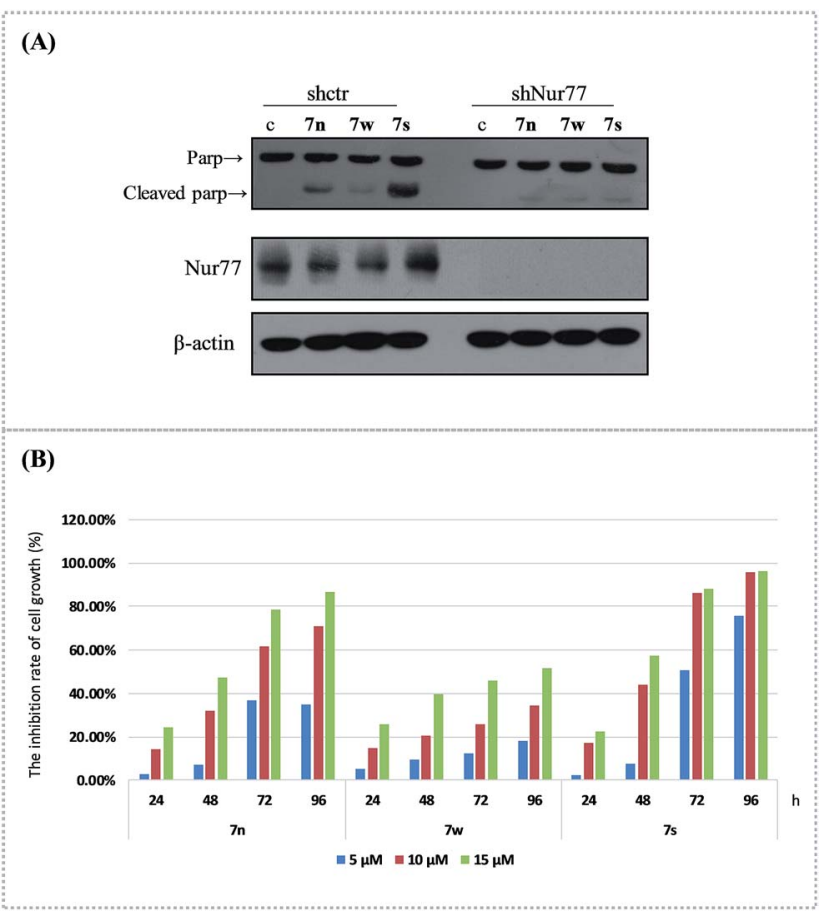

Fig. 2 The compounds induced apoptosis and inhibited growth of H460 cells. (A) Nur77 expression was required for the apoptotic effect of $7 n, 7 s$, and $7 w$ in $\mathrm{H} 460$ cells. $\mathrm{H} 460$ cancer cells were transfected with control or Nur77 shRNA for $24 \mathrm{~h}$, then treated with or without 10 $\mu \mathrm{M}$ of the compounds for an additional $24 \mathrm{~h}$. The Parp cleavage and Nur77 expression were analysed via western blotting. (B) Growth inhibition activities of compounds on $\mathrm{H} 460$ cells were assessed with MTT assay. $\mathrm{H} 460$ cancer cells treated with these three compounds at various concentrations $(5 \mu \mathrm{M}, 10 \mu \mathrm{M}$ and $15 \mu \mathrm{M})$ and tested at $24 \mathrm{~h}$, $48 \mathrm{~h}, 72 \mathrm{~h}$, and $96 \mathrm{~h}$ time points. DMSO was used as the negative control. 
the inhibition rates of $7 \mathbf{n}$ at the various concentrations $(5 \mu \mathrm{M}$, $10 \mu \mathrm{M}$ and $15 \mu \mathrm{M}$ ) were $35.02 \%, 70.73 \%$, and $86.50 \%$. The inhibition rates for $7 \mathbf{w}$ were $18.02 \%, 34.47 \%$, and $51.71 \%$. The inhibition rates for $7 \mathrm{~s}$ were $75.70 \%, 95.72 \%$, and $96.05 \%$. The anti-proliferation abilities of these three compounds were similar to their apoptosis induction and Nur77 activation effects in $\mathrm{H} 460$ cells.

(A)

(B)
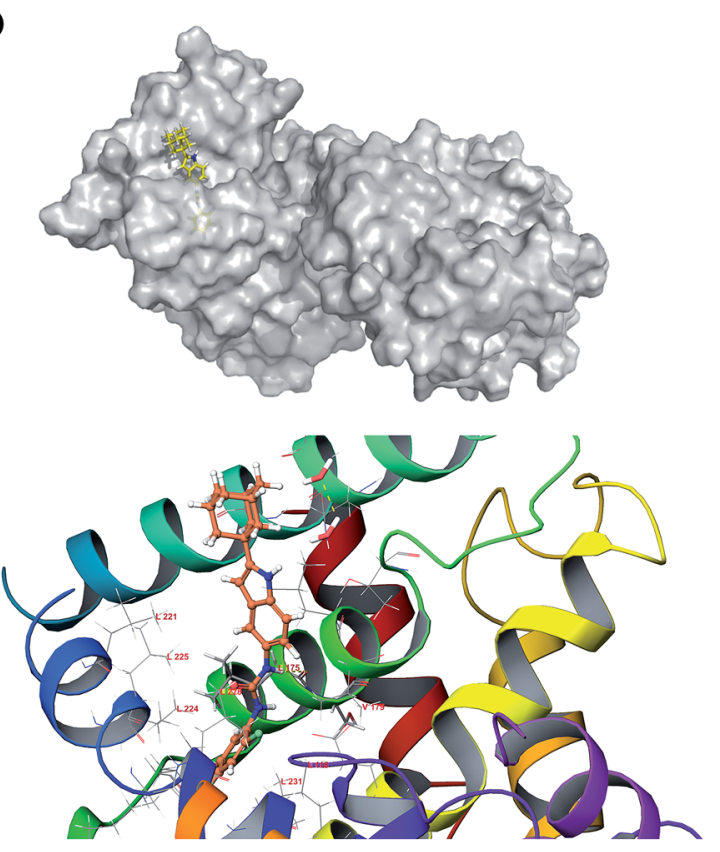

(C)

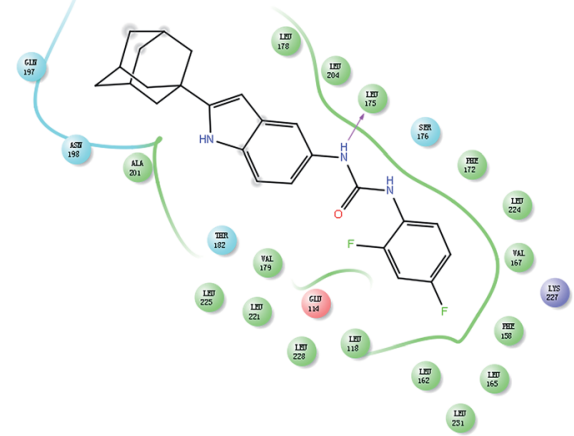

Fig. 3 Molecular docking 3D and 2D models of 7s and Nur77. (A) The interactions between Nur77 are displayed on the grey surface presentation. The $7 \mathrm{~s}$ is represented in the yellow stick. The protein surface conformation is the crystal structure of homodimer of the orphan nuclear receptor Nur77 (PDB ID: 4RE8). The moiety of difluorobenzene of ligand inserted deeply into the hydrophobic pocket. (B) Close-up view depiction of the superposition of Nur77 LBP bound to 7s. The Nur77 binding site is presented with a coloured ribbon. Neighbouring amino acids were displayed in lines within a distance of $5 \AA$ approximately to 7s (the hydrogen bond between 7s and LEU 175 are shown as yellow dots). (C) 2D binding model of $7 \mathrm{~s}$ with Nur77: hydrogen bonds are indicated with solid arrows, colour lines around $7 \mathrm{~s}$ stand for the binding pocket and the residues in colours nearby established the pocket. The green colour denotes the hydrophobic nature of amino acids, the red colour denotes the acid amino acids, the purple denotes the alkalinity of amino acids, the cyan denotes the polar amino acids, and the grey points of ligand atoms denotes the solvent accessibility.

\subsection{Molecular docking study of $7 \mathrm{~s}$ and Nur77}

The in vitro bioassay revealed the high ability of compound $7 \mathbf{s}$ when activating Nur77 in H460 cancer cells. We performed a molecular docking study for $7 \mathbf{s}$ and Nur77. The docking study revealed that compound $7 \mathrm{~s}$ exhibited a promising binding affinity with Nur77 with a docking binding energy of $-7.30 \mathrm{kcal} \mathrm{mol}^{-1}$. The specific non-bonded interactions between $7 \mathbf{s}$ and the residues of Nur77 in 3D and 2D are shown in Fig. 3. The urea group of compound $7 \mathbf{s}$ formed a hydrogen bonding interaction with the backbone's carbonyl group of amino acid LEU175. The moiety of difluorobenzene inserted deeply into the hydrophobic pocket formed by PHE172, LEU224, VAL167, PHE158, LEU162 and LEU118. The adamantine group extended out of the pocket and interacted with the surface of ALA201, ASN198, and GLN197 via hydrophobic interactions. The hydrogen bond between $7 \mathbf{s}$ and Nur77 could still exist even though the LEU175 mutated to other amino acids (like an alanine). This indicated that the hydrogen bond between 7s and the backbone of LEU175 could be important for the affinity and selection of the complex $7 \mathbf{s}-$ Nur77.

\section{Conclusion}

In this study, we synthesized and conducted a biological evaluation of two new series of 1-(2-(adamantan-1-yl)-1 $H$-indol-5-yl)3 -substituted urea/thiourea derivatives as potential anticancer agents. The synthetic method was relatively simple. The target compounds were easily purified and produced in high yields. Among of synthesized compounds, most showed moderate anti-proliferative activity against all three of the tested cancer cell lines. The compounds with prominent anticancer activity also exhibited good sensitivity between the normal (MRC-5) and the tumour (H460) cell lines that were isolated from lung tissue. Three compounds that could active Nur77 were obtained: $7 \mathbf{n}$, $7 \mathbf{s}$, and $\mathbf{7 w}$. They were evaluated for their abilities to induce apoptosis in various cells and the inhibition of cell growth in H460 cancer cells. The results showed that $\mathbf{7 n}$ and $7 \mathbf{s}$ achieved better anticancer activity than $7 \mathbf{w}$. The shRNA experiment revealed that the apoptosis effect of $7 \mathbf{n}$ and $7 \mathbf{s}$ was dependent on Nur77, particularly in $7 \mathbf{s}$. Compound $\mathbf{7 w}$ could have an alternative mechanism. The molecular docking suggested that compound $7 \mathbf{s}$ exhibited a promising binding affinity with Nur77. These results are helpful in the development of a Nur77 targeted drug. Further studies are also required to determine their roles in preventing cancer.

\section{Experimental section}

\subsection{Chemistry}

All reagents were commercially available and used without further purification, unless otherwise indicated. Reactions were magnetically stirred and monitored by thin-layer chromatography (TLC) on Merck silica gel 60F-254 by fluorescence. The target compounds were purified by column chromatography. The purities of the target compounds were assessed by high performance liquid chromatography (HPLC) with a COSMOSIL 
C18-MS-II column $(250 \mathrm{~mm} \times 4.6 \mathrm{~mm}$ i.d., $5 \mu \mathrm{m})$. The HPLC analysis was performed on an Agilent Technologies 1100 Series HPLC system. The mobile phase was acetonitrile (A) and water (B), eluted as the following gradient program: A from $80 \%$ to $100 \%$ and $\mathrm{B}$ from $20 \%$ to $0 \%$ during $0-20 \mathrm{~min}$. The flow rate was

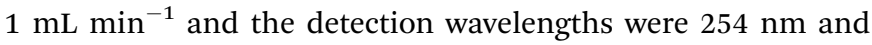
$280 \mathrm{~nm} .{ }^{1} \mathrm{H}-\mathrm{NMR}$ and ${ }^{13} \mathrm{C}-\mathrm{NMR}$ spectra were obtained using a Bruker AV2 600 Ultra shield spectrometer at 600 and $150 \mathrm{MHz}$ respectively. Chemical shifts were given in parts per million (ppm) relative to tetramethyl-silane (TMS) as an internal standard. Multiplicities were abbreviated as follows: single (s), doublet (d), doublet-doublet (dd), doublet-triplet (dt), triplet $(\mathrm{t})$, triplet-triplet $(\mathrm{tt})$, triplet-doublet $(\mathrm{td})$, quartet $(\mathrm{q})$, quartetdoublet (qd), multiplet (m), and broad signal (br s). Highresolution mass spectral (HRMS) data were acquired on a $\mathrm{Q}$ Exactive. Melting points were measured on a SGWX-4 micromelting point spectrometer and were uncorrected.

4.1.1. $\mathbf{N}$-o-Tolylcycloadamantanecarboxamide

(2). A mixture of $10.0 \mathrm{mmol}$ of $o$-toluidine, $10.0 \mathrm{mmol}$ of 1-adamantanecarbonyl chloride, and $7.0 \mathrm{mmol}$ of anhydrous potassium carbonate in $50 \mathrm{~mL}$ of toluene was stirred at room temperature for $4 \mathrm{~h}$. The resulting solid was first filtered off and stirred at room temperature for $1.5 \mathrm{~h}$ with $50 \mathrm{~mL}$ of $\mathrm{H}_{2} \mathrm{O}$. The solid was filtered off and recrystallized from the appropriate solvent. White solid (75.5\%). ${ }^{1} \mathrm{H}$ NMR (600 MHz, $\left.\mathrm{CDCl}_{3}\right): \delta 7.88$ $(\mathrm{d}, J=8.1 \mathrm{~Hz}, 1 \mathrm{H}, \mathrm{Ar}-\mathrm{H}), 7.18-7.24(\mathrm{~m}, 2 \mathrm{H}, \mathrm{C}=\mathrm{ONH}$ and $\mathrm{Ar}-\mathrm{H})$, $7.17(\mathrm{~d}, J=7.5 \mathrm{~Hz}, 1 \mathrm{H}, \mathrm{Ar}-\mathrm{H}), 7.05$ (dt, $J=1.1,7.4 \mathrm{~Hz}, 1 \mathrm{H}, \mathrm{Ar}-\mathrm{H})$, $2.26\left(\mathrm{~s}, 3 \mathrm{H}, \mathrm{Ar}-\mathrm{CH}_{3}\right), 1.99-2.13(\mathrm{~m}, 3 \mathrm{H}, \mathrm{Ad}-\mathrm{H}), 1.97-2.01(\mathrm{~m}, 6 \mathrm{H}$, Ad-H), 1.73-1.80 (m, 6H, Ad-H); ESI-HRMS (+): $m / z[\mathrm{M}+\mathrm{H}]^{+}$ calculated for $\mathrm{C}_{18} \mathrm{H}_{24} \mathrm{NO}^{+}, 270.1852$, found 270.1853; [M $\left.+\mathrm{Na}\right]^{+}$ calculated for $\mathrm{C}_{18} \mathrm{H}_{23} \mathrm{NONa}^{+}$, 292.1672, found 292.1669.

4.1.2. 2-Adamantane- $\mathbf{H}$-indole (3). A stirred solution of $10 \mathrm{mmol}$ of $\mathrm{N}$-o-tolylcycloadamantanecarboxamide (2) in $50 \mathrm{~mL}$ of THF under a $\mathrm{N}_{2}$ atmosphere was maintained at an internal temperature of -5 to $5{ }^{\circ} \mathrm{C}$ and treated dropwise with 0.1$0.15 \mathrm{~mol}$ of $n$-BuLi as $2.5 \mathrm{M} n$-BuLi in hexane. The stirred mixture was kept at ambient temperature, cooled in an ice bath, and treated dropwise with $12 \mathrm{~mL}$ of $2 \mathrm{M} \mathrm{HCl}$. The organic layer was separated and the aqueous layer washed with $\mathrm{C}_{6} \mathrm{H}_{6}$. The combined organic layer was dried with anhydrous $\mathrm{MgSO}_{4}$, filtered, and concentrated in vacuo. Recrystallization of the residue was from the appropriate solvent. White solid (56.5\%). ${ }^{1} \mathrm{H}$ NMR $\left(600 \mathrm{MHz}, \mathrm{CDCl}_{3}\right): \delta 7.30(\mathrm{~d}, J=7.9 \mathrm{~Hz}, 1 \mathrm{H}, \mathrm{Ar}-\mathrm{H}), 7.18$ (dd, $J=0.6,8.1 \mathrm{~Hz}, 1 \mathrm{H}, \mathrm{Ar}-\mathrm{H}), 6.88(\mathrm{dt}, J=1.1,7.5 \mathrm{~Hz}, 1 \mathrm{H}, \mathrm{Ar}-$ H), 6.77-6.83 (m, 1H, Ar-H), 5.98 (d, $\left.J=0.6 \mathrm{~Hz}, 1 \mathrm{H}, \mathrm{H}-3^{\prime}\right), 1.96-$ $2.00(\mathrm{~m}, 3 \mathrm{H}, \mathrm{Ad}-\mathrm{H}), 1.91-1.94(\mathrm{~m}, 6 \mathrm{H}, \mathrm{Ad}-\mathrm{H}), 1.70-1.78(\mathrm{~m}, 6 \mathrm{H}$, Ad-H); ESI-HRMS (+): $m / z[\mathrm{M}+\mathrm{H}]^{+}$calculated for $\mathrm{C}_{18} \mathrm{H}_{22} \mathrm{~N}^{+}$, 252.1747, found 252.1748; $[\mathrm{M}+\mathrm{Na}]^{+}$calculated for $\mathrm{C}_{18} \mathrm{H}_{21} \mathrm{NNa}^{+}$, 274.1566, found 274.1568 .

4.1.3. 2-Adamantane-5-nitro- $\mathbf{H}$-indole (4). In a $250 \mathrm{~mL}$ round-bottom flask, $2.51 \mathrm{~g}$ of 2 -adamantane- $1 H$-indole (10 mmol) was dissolved in $10 \mathrm{~mL}$ of $\mathrm{H}_{2} \mathrm{SO}_{4}$ after vigorous stirring. In a separate flask, $0.94 \mathrm{~g}$ of $\mathrm{NaNO}_{3}(1.1 \times 10 \mathrm{mmol})$ was dissolved in $10 \mathrm{~mL}$ of $\mathrm{H}_{2} \mathrm{SO}_{4}$, also after vigorous stirring, and then was added dropwise (via addition funnel) to the above mixture. After addition, the reaction mixture was stirred for another $10 \mathrm{~min}$ and then poured into $200 \mathrm{~mL}$ of ice water, precipitating a yellow product. The product was isolated via filtration and washed with cold water. After $12 \mathrm{~h}$ of drying under vacuum, $2.89 \mathrm{~g}$ of yellow product was isolated $(97 \%) .{ }^{1} \mathrm{H} \mathrm{NMR}(600 \mathrm{MHz}$, DMSO-d ${ }_{6}$ ): $\delta 11.65$ (br s, $\left.1 \mathrm{H}, \mathrm{NH}\right), 8.44(\mathrm{~d}, J=2.2 \mathrm{~Hz}, 1 \mathrm{H}, \mathrm{Ar}-\mathrm{H})$, $7.93(\mathrm{dd}, J=2.2,9.0 \mathrm{~Hz}, 1 \mathrm{H}, \mathrm{Ar}-\mathrm{H}), 7.44(\mathrm{~d}, J=8.8 \mathrm{~Hz}, 1 \mathrm{H}, \mathrm{Ar}-$ $\mathrm{H}), 6.38$ (d, $\left.J=1.5 \mathrm{~Hz}, 1 \mathrm{H}, \mathrm{H}-3^{\prime}\right), 2.04-2.08$ (m, 3H, Ad-H), 1.961.99 (m, 6H, Ad-H), 1.72-1.80 (m, 6H, Ad-H); ${ }^{13} \mathrm{C}$ NMR (150 MHz, DMSO-d $\left.{ }_{6}\right): \delta 154.0\left(\mathrm{C}-2^{\prime}\right), 140.8\left(\mathrm{C}-\mathrm{NO}_{2}\right), 139.9(\mathrm{Ar}-\mathrm{CH})$, 127.7 (Ar-C), 116.9 (Ar-C), 116.3 (Ar-CH), 111.4 (Ar-CH), 98.2 (C-3'), 41.9 (Ad-C), 36.6 (s, 3C, Ad-C), 34.1 (s, 3C, Ad-C), 28.2 (s, $3 \mathrm{C}$, Ad-C); ESI-HRMS (+): $m / z[\mathrm{M}+\mathrm{H}]^{+}$calculated for $\mathrm{C}_{18} \mathrm{H}_{21} \mathrm{~N}_{2} \mathrm{O}_{2}{ }^{+}$, 297.1598, found 297.1599; $[\mathrm{M}+\mathrm{Na}]^{+}$calculated for $\mathrm{C}_{18} \mathrm{H}_{20} \mathrm{~N}_{2} \mathrm{O}_{2} \mathrm{Na}^{+}$, 319.1417, found 319.1417.

4.1.4. 2-Adamantane- $\mathbf{H}$-indol-5-amine (5). Compound 4 $(2.96 \mathrm{~g}, 10 \mathrm{mmol})$ was dissolved in $150 \mathrm{~mL}$ of ethanol. $10 \% \mathrm{Pd} / \mathrm{C}$ was added (300 mg), and the mixture was subjected to $\mathrm{H}_{2}$ (38 psi) using a Parr hydrogenator for $3.5 \mathrm{~h}$. The mixture was filtered over Celite, which was washed with methanol. After concentration and drying under vacuum, $2.5 \mathrm{~g}$ of a brown powder (94\%) was isolated. ${ }^{1} \mathrm{H} \mathrm{NMR}\left(600 \mathrm{MHz}, \mathrm{CDCl}_{3}\right): \delta 7.80(\mathrm{~s}$, $1 \mathrm{H}, \mathrm{NH}), 7.10$ (d, $J=8.4 \mathrm{~Hz}, 1 \mathrm{H}, \mathrm{Ar}-\mathrm{H}), 6.86$ (d, $J=2.2 \mathrm{~Hz}, 1 \mathrm{H}$, $\mathrm{Ar}-\mathrm{H}), 6.57$ (dd, $J=2.2,8.4 \mathrm{~Hz}, 1 \mathrm{H}, \mathrm{Ar}-\mathrm{H}), 6.05(\mathrm{dd}, J=2.2 \mathrm{~Hz}$, $1 \mathrm{H}, \mathrm{H}-3^{\prime}$ ), 3.45 (br s, $2 \mathrm{H}, \mathrm{NH}_{2}$ ), 2.06-2.12 (m, 3H, Ad-H), 1.941.98 (m, 6H, Ad-H), 1.75-1.81 (m, 6H, Ad-H); ${ }^{13} \mathrm{C}$ NMR (150 $\left.\mathrm{MHz}, \mathrm{CDCl}_{3}\right): \delta 149.9\left(\mathrm{C}-2^{\prime}\right), 139.3\left(\mathrm{C}-\mathrm{NH}_{2}\right), 130.3(\mathrm{Ar}-\mathrm{C}), 129.4$ (Ar-C), $111.6(\mathrm{Ar}-\mathrm{CH}), 110.8(\mathrm{Ar}-\mathrm{CH}), 105.3(\mathrm{Ar}-\mathrm{CH}), 95.5\left(\mathrm{C}-3^{\prime}\right)$, 42.6 (Ad-C), 36.8 (s, 3C, Ad-C), 33.7 (s, 3C, Ad-C), 28.5 (s, 3C, Ad-C); ESI-HRMS (+): $m / z[\mathrm{M}+\mathrm{H}]^{+}$calculated for $\mathrm{C}_{18} \mathrm{H}_{23} \mathrm{~N}_{2}{ }^{+}$, 267.1856, found 267.1858 .

4.1.5. 5-Isocyanato- $1 H$-indole-adamantane (6). To a solution of ethyl 5-amino- $1 H$-indole-2-adamantane $2.66 \mathrm{~g}$ (10.0 $\mathrm{mmol}$ ) dissolved in THF ( $80 \mathrm{~mL})$ was slowly dropped into a stirred solution of triphosgene $2.98 \mathrm{~g},(10.0 \mathrm{mmol})$ in THF $(10 \mathrm{~mL})$ by using a constant-pressure dropping funnel. $\mathrm{NEt}_{3}(3 \mathrm{~mL}, 21.0$ mmol) was then added slowly to the reaction mixture after the ethyl 5-amino- $1 H$-indole-2-adamantane was added. The reaction mixture was stirred at $0{ }^{\circ} \mathrm{C}$ for $2 \mathrm{~h}$. After completion of the reaction, the mixture was concentrated and purified by column chromatography using appropriate mixtures of EtOAc and PE to yield the titled compound. White solid (61.5\%). ${ }^{1} \mathrm{H}$ NMR (600 $\mathrm{MHz}_{\mathrm{CDCl}}$ ): $\delta 8.01(\mathrm{~s}, 1 \mathrm{H}, \mathrm{NH}), 7.21(\mathrm{~d}, J=8.4 \mathrm{~Hz}, 1 \mathrm{H}, \mathrm{Ar}-\mathrm{H})$, $6.85(\mathrm{dd}, J=2.0,8.4 \mathrm{~Hz}, 1 \mathrm{H}, \mathrm{Ar}-\mathrm{H}), 6.17\left(\mathrm{~d}, J=1.5 \mathrm{~Hz}, 1 \mathrm{H}, \mathrm{H}-3^{\prime}\right)$, 2.07-2.15 (m, 3H, Ad-H), 1.95-2.00 (m, 6H, Ad-H), 1.74-1.85 (m, $6 \mathrm{H}, \mathrm{Ad}-\mathrm{H}) ;{ }^{13} \mathrm{C}$ NMR $\left(150 \mathrm{MHz}, \mathrm{CDCl}_{3}\right): \delta 151.0\left(\mathrm{C}-2^{\prime}\right), 133.2(\mathrm{Ar}-$ C), $129.0(\mathrm{Ar}-\mathrm{C}), 125.1(\mathrm{Ar}-\mathrm{C}), 123.6(\mathrm{~N}=\mathrm{C}=\mathrm{O}), 118.1(\mathrm{Ar}-\mathrm{CH})$, 115.5 (Ar-CH), 111.1 (Ar-CH), $96.4\left(\mathrm{C}-3^{\prime}\right), 42.5$ (Ad-C), 36.7 (s, 3C, Ad-C), 33.8 (s, 3C, Ad-C), 28.4 (s, 3C, Ad-C).

4.1.6. General method for the synthesis of compounds $7 \mathrm{a}-$ $7 y$. To a solution of 5-isocyanato- $1 H$-indole-adamantine 6 $(0.12 \mathrm{~g}, 0.4 \mathrm{mmol})$ in toluene $(5 \mathrm{~mL})$ aliphatic, aromatic or heteroaromatic amine $(0.4 \mathrm{mmol})$ was added, and the reaction mixture was heated at $60{ }^{\circ} \mathrm{C}$ for $4 \mathrm{~h}$. After completion of the reaction, the mixture was concentrated and purified by column chromatography using appropriate mixtures of $\mathrm{CH}_{2} \mathrm{Cl}_{2}$ and $\mathrm{MeOH}$.

4.1.6.1 Compound 7n. White solid; yield: 87.3\%; HPLC purity: $95.5 \%\left(t_{\mathrm{R}}=21.05 \mathrm{~min}\right)$; $\mathrm{mp}: 265-267{ }^{\circ} \mathrm{C} ;{ }^{1} \mathrm{H}$ NMR $(600$ 
MHz, DMSO-d $\left.{ }_{6}\right): \delta 10.74\left(\mathrm{~s}, 1 \mathrm{H}, \mathrm{NH}^{\prime} \mathrm{1}^{\prime}\right), 8.90(\mathrm{~s}, 1 \mathrm{H}, \mathrm{C}=\mathrm{ONH}-1)$, $8.46(\mathrm{~s}, 1 \mathrm{H}, \mathrm{C}=\mathrm{ONH}-3), 8.04\left(\mathrm{~s}, 1 \mathrm{H}, \mathrm{H}-2^{\prime}\right), 7.56(\mathrm{~d}, J=1.5 \mathrm{~Hz}, 1 \mathrm{H}$, $\mathrm{H}-4^{\prime}$ ), 7.54-7.56 (m, 1H, Ar-H), 7.46-7.51 (m, 1H, Ar-H), 7.27 (d, $J=7.7 \mathrm{~Hz}, 1 \mathrm{H}, \mathrm{Ar}-\mathrm{H}), 7.21$ (d, $\left.J=8.4 \mathrm{~Hz}, 1 \mathrm{H}, \mathrm{H}-7^{\prime}\right), 7.01$ (dd, $J=$ 2.0, 8.4 Hz, 1H, H-6'), 6.03 (d, $\left.J=1.7 \mathrm{~Hz}, 1 \mathrm{H}, \mathrm{H}-3^{\prime}\right), 2.03-2.08$ (m, $3 \mathrm{H}, \mathrm{Ad}-\mathrm{H}), 1.92-1.99$ (m, 6H, Ad-H), 1.72-1.80 (m, Ad-H); ${ }^{13} \mathrm{C}$ NMR (150 MHz, DMSO-d 6 ): $\delta 153.4(\mathrm{C}=\mathrm{O}), 150.8\left(\mathrm{C}-2^{\prime}\right), 141.5$ $\left(\mathrm{C}-1^{\prime \prime}\right), 133.0\left(\mathrm{C}-8^{\prime}\right), 131.1\left(\mathrm{C}-5^{\prime}\right), 130.3\left(\mathrm{C}-5^{\prime \prime}\right), 129.96$ (q, $J=$ $30.8 \mathrm{~Hz}, \mathrm{CF}_{3} \mathrm{C}$ ), 128.4 (C-9'), 124.8 (q, $\left.J=271.8 \mathrm{~Hz}, \mathrm{CF}_{3}\right), 122.0$ (C-6"), 118.0 (q, $\left.J=4.4 \mathrm{~Hz}, \mathrm{C}-2^{\prime \prime}\right), 114.35\left(\mathrm{C}-6^{\prime}\right), 114.30$ (q, $J=$ $\left.4.4 \mathrm{~Hz}, \mathrm{C}-4^{\prime \prime}\right) 111.1\left(\mathrm{C}-7^{\prime}\right), 110.5\left(\mathrm{C}-4^{\prime}\right), 95.4\left(\mathrm{C}-3^{\prime}\right), 42.3$ (Ad-C), 36.8 (s, 3C, Ad-C), 33.9 (s, 3C, Ad-C), 28.4 (s, 3C, Ad-C); ESIHRMS (+): $m / z[\mathrm{M}+\mathrm{H}]^{+}$calculated for $\mathrm{C}_{26} \mathrm{H}_{27} \mathrm{~F}_{3} \mathrm{~N}_{3} \mathrm{O}^{+}$, 454.2101, found 454.2101; $[\mathrm{M}+\mathrm{Na}]^{+}$calculated for $\mathrm{C}_{26} \mathrm{H}_{26} \mathrm{~F}_{3}$ $\mathrm{N}_{3} \mathrm{ONa}^{+}, 476.192$, found 476.1922 .

4.1.6.2 Compound 7s. White solid; yield: 89.6\%; HPLC purity: $96.4 \%\left(t_{\mathrm{R}}=17.89 \mathrm{~min}\right)$; $\mathrm{mp}: 178-181{ }^{\circ} \mathrm{C} ;{ }^{1} \mathrm{H}$ NMR $(600$ MHz, DMSO-d ${ }_{6}$ ): $\delta 10.73\left(\mathrm{~d}, J=1.3 \mathrm{~Hz}, 1 \mathrm{H}, \mathrm{NH}-1^{\prime}\right), 8.72(\mathrm{~s}, 1 \mathrm{H}$, $\mathrm{C}=\mathrm{ONH}-1), 8.36(\mathrm{~d}, J=2.0 \mathrm{~Hz}, 1 \mathrm{H}, \mathrm{C}=\mathrm{ONH}-3), 8.12-8.17(\mathrm{~m}$, $\left.1 \mathrm{H}, 6^{\prime \prime}\right), 7.56\left(\mathrm{~d}, J=1.8 \mathrm{~Hz}, 1 \mathrm{H}, \mathrm{H}-4^{\prime}\right), 7.26-7.30\left(\mathrm{~m}, 1 \mathrm{H}, 5^{\prime \prime}\right), 7.20$ $\left(\mathrm{d}, J=8.4 \mathrm{~Hz}, 1 \mathrm{H}, 7^{\prime}\right), 7.01-7.05\left(\mathrm{~m}, 1 \mathrm{H}, \mathrm{H}-3^{\prime \prime}\right), 6.99$ (dd, $J=2.1$, $\left.8.5 \mathrm{~Hz}, 1 \mathrm{H}, \mathrm{H}-6^{\prime}\right), 6.02$ (d, $\left.J=1.7 \mathrm{~Hz}, 1 \mathrm{H}, \mathrm{H}-3^{\prime}\right), 2.03-2.08(\mathrm{~m}, 3 \mathrm{H}$, Ad-H), 1.93-1.98 (m, 6H, Ad-H), 1.72-1.80 (m, 6H, Ad-H); ${ }^{13} \mathrm{C}$ NMR (150 MHz, DMSO-d $\left.)_{6}\right): \delta 156.8$ (dd, $J=12.1,241.0 \mathrm{~Hz}, \mathrm{CF}-$ $2^{\prime \prime}$ ), $153.1(\mathrm{C}=\mathrm{O}), 152.3\left(\mathrm{dd}, J=12.1,241.5 \mathrm{~Hz}, \mathrm{CF}-4^{\prime \prime}\right), 150.8$ (C-

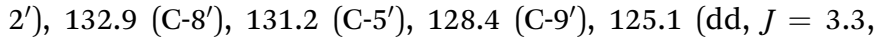
$\left.11.0 \mathrm{~Hz}, \mathrm{C}-1^{\prime \prime}\right), 121.9$ (dd, $\left.J=3.3,8.8 \mathrm{~Hz}, \mathrm{C}-6^{\prime \prime}\right), 113.9\left(\mathrm{C}-6^{\prime}\right), 111.4$ (dd, $\left.J=23.1,24.2 \mathrm{~Hz}, \mathrm{C}-5^{\prime \prime}\right), 111.1\left(\mathrm{C}-7^{\prime}\right), 110.0\left(\mathrm{C}-4^{\prime}\right), 104.1$ (dd, $J$ = 3.3, 21.3 Hz, C-3"), 95.4 (C-3'), 42.3 (Ad-C), 36.8 (s, 3C, Ad-C), 33.9 (s, 3C, Ad-C), 28.4 (s, 3C, Ad-C); ESI-HRMS (+): $m / z[\mathrm{M}+\mathrm{H}]^{+}$ calculated for $\mathrm{C}_{25} \mathrm{H}_{26} \mathrm{~F}_{2} \mathrm{~N}_{3} \mathrm{O}^{+}$422.2038, found 422.2030; [M + $\mathrm{Na}]^{+}$calculated for $\mathrm{C}_{25} \mathrm{H}_{25} \mathrm{~F}_{2} \mathrm{~N}_{3} \mathrm{ONa}^{+}, 444.1850$, found 444.1852 . (ESI Fig. S1 $\dagger$ )

4.1.6.3 Compound $7 w$. White solid; yield: $85.8 \%$; HPLC purity: $94.8 \%\left(t_{\mathrm{R}}=20.80 \mathrm{~min}\right)$; $\mathrm{mp}: 271-273{ }^{\circ} \mathrm{C} ;{ }^{1} \mathrm{H}$ NMR $(600$ MHz, DMSO-d ${ }_{6}$ ): $\delta 10.74$ (s, $\left.1 \mathrm{H}, \mathrm{NH}^{\prime} \mathbf{1}^{\prime}\right), 8.76(\mathrm{~s}, 1 \mathrm{H}, \mathrm{C}=\mathrm{ONH}-1)$, $8.55(\mathrm{~s}, 1 \mathrm{H}, \mathrm{C}=\mathrm{ONH}-3), 7.88-7.98\left(\mathrm{~m}, 1 \mathrm{H}, \mathrm{H}-6^{\prime \prime}\right), 7.56(\mathrm{~d}, J=$ $\left.1.7 \mathrm{~Hz}, 1 \mathrm{H}, \mathrm{H}-4^{\prime}\right), 7.23-7.27\left(\mathrm{~m}, 1 \mathrm{H}, \mathrm{H}-5^{\prime \prime}\right), 7.21$ (d, $J=8.6 \mathrm{~Hz}$, $\left.1 \mathrm{H}, 7^{\prime}\right) 6.99\left(\mathrm{dd}, J=2.0,8.6 \mathrm{~Hz}, 1 \mathrm{H}, \mathrm{H}-6^{\prime}\right), 6.03(\mathrm{~d}, J=1.7 \mathrm{~Hz}, 1 \mathrm{H}$, H-3'), 2.03-2.08 (m, 3H, Ad-H), 1.93-1.98 (m, 6H, Ad-H), 1.72-

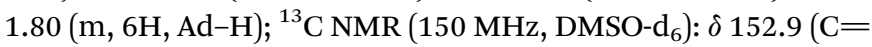
O), $150.8\left(\mathrm{C}-2^{\prime}\right), 145.3$ (ddd, $\left.J=2.2,9.9,242.1 \mathrm{~Hz}, \mathrm{CF}-2^{\prime \prime}\right), 141.7$ (ddd, $J=3.3,11.0,245.4 \mathrm{~Hz}, \mathrm{CF}-4^{\prime \prime}$ ), 139.5 (dt, $J=14.3,246.5 \mathrm{~Hz}$, CF-3"), 126.5 (dd, $\left.J=3.3,7.7 \mathrm{~Hz}, \mathrm{C}-6^{\prime \prime}\right), 133.0\left(\mathrm{C}-8^{\prime}\right), 131.0\left(\mathrm{C}-5^{\prime}\right)$, $128.4\left(\mathrm{C}-9^{\prime}\right), 115.2$ (m, C-1"1), $114.0\left(\mathrm{C}-6^{\prime}\right), 112.1$ (dd, $J=3.3$, 17.1 Hz, C-5"), 111.1 (C-7'), 110.1 (C-4'), 95.4 (C-3'), 42.3 (Ad-C), 36.8 (s, 3C, Ad-C), 33.9 (s, 3C, Ad-C), 28.4 (s, 3C, Ad-C); ESIHRMS (+): $m / z[\mathrm{M}+\mathrm{H}]^{+}$calculated for $\mathrm{C}_{25} \mathrm{H}_{25} \mathrm{~F}_{3} \mathrm{~N}_{3} \mathrm{O}^{+}$, 440.1944, found 440.1938; $[\mathrm{M}+\mathrm{Na}]^{+}$calculated for $\mathrm{C}_{25} \mathrm{H}_{24} \mathrm{~F}_{3^{-}}$ $\mathrm{N}_{3} \mathrm{ONa}^{+}, 462.1764$, found 462.1760 .

At the series of urea derivatives, the other target compounds were synthesized following the general procedure as described above with the yield of 84-90\%. Their structures were confirmed by the spectroscopic data including ${ }^{1} \mathrm{H}$ NMR, ${ }^{13} \mathrm{C}$ NMR, and ESIHRMS (see 'ESI†').

4.1.7. 5-Isocyanato- $\mathbf{H}$-indole-adamantane (8). To a solution of ethyl 5-amino- $1 H$-indole-2-adamantane $(4.1 \mathrm{~g}, 15.5$ $\mathrm{mmol})$ and triethylenediamine $(2.08 \mathrm{~g}, 18.6 \mathrm{mmol})$ in $40 \mathrm{~mL}$ of toluene, $\mathrm{CS}_{2}(3.5 \mathrm{~g}, 46.5 \mathrm{mmol})$ was added slowly. The resulting mixture was stirred at room temperature for $8 \mathrm{~h}$. After filtration, the filter cake was washed with toluene and dried. Obtained intermediate was suspended in $40 \mathrm{~mL}$ of DCM. Then, a $25 \mathrm{~mL}$ of DCM solution of BTC $(5.0 \mathrm{~g}, 17.0 \mathrm{mmol})$ was added slowly under $0-5{ }^{\circ} \mathrm{C}$. The mixture was stirred for $2 \mathrm{~h}$ at room temperature, and then was refluxed for 1.5-2 h. After filtration, the filtrate was concentrated in vacuo. The mixture was concentrated and purified by column chromatography using appropriate mixtures of EtOAc and PE to yield the titled compound. White solid (62.5\%). ${ }^{1} \mathrm{H}$ NMR (600 MHz, $\mathrm{CDCl}_{3}$ ): $\delta 8.12$ (br s, $\left.1 \mathrm{H}, \mathrm{NH}\right), 7.40$ $\left(\mathrm{d}, J=1.8 \mathrm{~Hz}, 1 \mathrm{H}, \mathrm{H}-4^{\prime}\right), 7.23\left(\mathrm{~d}, J=8.4 \mathrm{~Hz}, 1 \mathrm{H}, \mathrm{H}-7^{\prime}\right), 6.98(\mathrm{dd}, J$ $\left.=2.0,8.4 \mathrm{~Hz}, 1 \mathrm{H}, \mathrm{H}-6^{\prime}\right), 6.20\left(\mathrm{~d}, J=1.5 \mathrm{~Hz}, 1 \mathrm{H}, \mathrm{H}-3^{\prime}\right), 2.08-2.14$ (m, 3H, Ad-H), 1.94-1.99 (m, 6H, Ad-H), 1.74-1.85 (m, 6H, Ad$\mathrm{H}) ;{ }^{13} \mathrm{C}-\mathrm{NMR}\left(150 \mathrm{MHz}, \mathrm{CDCl}_{3}\right): \delta 151.4\left(\mathrm{C}-2^{\prime}\right), 134.1\left(\mathrm{C}-8^{\prime}\right), 131.8$ $\left(\mathrm{C}-9^{\prime}\right), 128.7\left(\mathrm{C}-5^{\prime}\right), 122.6(\mathrm{~N}=\mathrm{C}=\mathrm{S}), 119.0\left(\mathrm{C}-6^{\prime}\right), 117.3\left(\mathrm{C}-7^{\prime}\right)$, $111.2\left(\mathrm{C}-4^{\prime}\right), 96.8\left(\mathrm{C}-3^{\prime}\right), 42.5$ (Ad-C), 36.7 (s, 3C, Ad-C), 33.9 (s, 3C, Ad-C), 28.4 (s, 3C, Ad-C).

4.1.8. General method for the synthesis of compounds 9a9o. To a solution of 5 -isocyanato- $1 H$-indole-adamantane (8) $(0.12 \mathrm{~g}, 0.4 \mathrm{mmol})$ in toluene $(5 \mathrm{~mL})$, aliphatic, aromatic, or heteroaromatic amine $(0.4 \mathrm{mmol})$ was added, and the reaction mixture was heated at $60{ }^{\circ} \mathrm{C}$ for $4 \mathrm{~h}$. After completion of the reaction, the mixture was concentrated and purified by column chromatography using appropriate mixtures of $\mathrm{CH}_{2} \mathrm{Cl}_{2}$ and $\mathrm{MeOH}$.

4.1.8.1 Compound 9a. White solid; yield: 84.6\%; mp: 285$287{ }^{\circ} \mathrm{C}$; HPLC purity: $97.3 \%\left(t_{\mathrm{R}}=21.07 \mathrm{~min}\right) ;{ }^{1} \mathrm{H}$ NMR $(600$ MHz, DMSO-d ${ }_{6}$ ): $\delta 10.89$ (s, 1H, NH-1'), 9.15 (s, 1H, C=SNH-1), $7.32\left(\mathrm{~d}, J=1.7 \mathrm{~Hz}, 1 \mathrm{H}, \mathrm{H}-4^{\prime}\right), 7.25\left(\mathrm{~d}, J=8.4 \mathrm{~Hz}, 1 \mathrm{H}, \mathrm{H}-7^{\prime}\right), 6.87$ (dd, $J=1.9,8.5 \mathrm{~Hz}, 1 \mathrm{H}, \mathrm{H}-6^{\prime}$ ), 6.73 (br s, $\left.1 \mathrm{H}, \mathrm{C}=\mathrm{SNH}-3\right), 6.07$ (d, $\left.J=1.5 \mathrm{~Hz}, 1 \mathrm{H}, \mathrm{H}-3^{\prime}\right), 2.03-2.09$ (m, 3H, Ad-H), 1.93-1.98 (m, 6H, Ad-H), 1.72-1.80 (m, 6H, Ad-H), 1.45 (s, 9H, $\left.\left(\mathrm{CH}_{3}\right)_{3} \mathrm{C}\right) ;{ }^{13} \mathrm{C} \mathrm{NMR}$ (150 MHz, DMSO-d $\left.\mathrm{d}_{6}\right): \delta 180.3(\mathrm{C}=\mathrm{S}), 151.1\left(\mathrm{C}-2^{\prime}\right), 134.3\left(\mathrm{C}-8^{\prime}\right)$, $130.2\left(\mathrm{C}-5^{\prime}\right), 128.4\left(\mathrm{C}-9^{\prime}\right), 118.9\left(\mathrm{C}-6^{\prime}\right), 116.5\left({\mathrm{C}-7^{\prime}}^{\prime}\right), 111.3\left(\mathrm{C}-4^{\prime}\right)$, $95.7\left(\mathrm{C}-3^{\prime}\right), 53.0\left(\left(\mathrm{CH}_{3}\right)_{3} \mathrm{C}\right), 42.2(\mathrm{Ad}-\mathrm{C}), 36.8$ (s, 3C, Ad-C), 33.9 (s, 3C, Ad-C), 29.2 (s, 3C, $\left.\left(\mathrm{CH}_{3}\right)_{3} \mathrm{C}\right), 28.4$ (s, 3C, Ad-C); ESI-HRMS $(+): m / z[\mathrm{M}+\mathrm{H}]^{+}$calculated for $\mathrm{C}_{23} \mathrm{H}_{32} \mathrm{~N}_{3} \mathrm{~S}^{+}$, 382.2311, found 382.2307; $[\mathrm{M}+\mathrm{Na}]^{+}$calculated for $\mathrm{C}_{23} \mathrm{H}_{31} \mathrm{~N}_{3} \mathrm{SNa}^{+}$, 404.2131, found 404.2126 .

At the series of thiourea derivatives, the other final compounds were synthesized following the general procedure as described above with the yield of $84-92 \%$. Their structures were characterized by NMR, ESI-HRMS and HPLC analyses. (see 'ESI†').

\subsection{Biology materials and methods}

4.2.1. Reagents and antibodies. 3-(4,5-Dimethylthiazol-2yl)-2,5-diphenyltetrazoliumbromide (MTT) and DMSO were purchased from Sigma-Aldrich. TurboFect Transfection Reagent, goat anti-rabbit and anti-mouse secondary antibody conjugated to horseradish peroxidase were from Thermo Fisher Scientific. Anti-Nur77 (3960S), anti-poly (ADP ribose) polymerase (Parp) (9542) and anti- $\beta$-actin (4970) were from Cell Signal Technology. Enhanced chemiluminescence reagents 
from GE Healthcare and a cocktail of proteinase inhibitors from Roche were used in this study. All other chemicals used were commercial products of analytic grade obtained from Sigma.

4.2.2. Cell culture. All of the human cancer cell lines were obtained from the American Type Culture Collection (ATCC). MCR-5 normal lung cells were cultured in minimum essential medium (MEM) supplemented with 10\% fetal bovine serum and kept in a $\mathrm{CO}_{2}$ incubator which consisted of a humidified atmosphere of $5 \% \mathrm{CO}_{2}$ at $37{ }^{\circ} \mathrm{C}$ with $90 \%$ humidity. NCI-H460 lung cancer cells and $\mathrm{LO} 2$ normal hepatocytes cells were maintained in RPMI 1640 medium supplemented with 10\% fetal bovine serum, at $37{ }^{\circ} \mathrm{C}$ under $5 \% \mathrm{CO} 2 / 95 \%$ air. MCF-7 breast cancer cells, HepG2 liver cancer cells, and NIH-3T3 mouse embryo cells were grown in Dulbeccos Modifed Eagles Medium (DMEM) supplemented with 10\% fetal bovine serum in a humidified atmosphere containing $5 \% \mathrm{CO}_{2}$ at $37{ }^{\circ} \mathrm{C}$.

4.2.3. MTT assays. Cells were cultured in 96-well plate with $100 \mu \mathrm{L}$ medium and the total amount of cells in each well was about $1 \times 10^{4}$. Concentration gradients (5-7 different concentrations) of each compound were then added to cells (three repeats), cisplatin (DDP) as the positive control and dimethyl sulfoxide (DMSO) as the negative control. After $48 \mathrm{~h}$ treatment, $10 \mu \mathrm{L}$ MTT ( $5 \mathrm{mg} \mathrm{mL}^{-1}$ ) was added to each wells staining for 4 hours in cell incubator. Then in each well, medium was discarded and $100 \mu \mathrm{L}$ DMSO was used, after short time shaking, the light intensity was measured at a wavelength of $490 \mathrm{~nm}$ in Microplate Reader (Thermo). At last, the $\mathrm{IC}_{50}$ values (concentrations required to inhibit $50 \%$ of cell growth) were calculated using GraphPad Prism 5 software and cell inhibition curves were conducted.

4.2.4. Western blotting. Equal amounts of cell lysates were electrophoresed on $10 \%$ SDS polyacrylamide gel electrophoresis and transferred to the polyvinylidene difluoride (PVDF) membranes $(0.22 \mu \mathrm{M})$. The membranes were blocked with $5 \%$ nonfat milk in TBST buffer (50 mM Tris-HCl, pH7.4, $150 \mathrm{mM}$ $\mathrm{NaCl}$ and $0.1 \%$ Tween 20 ) for $1 \mathrm{~h}$ at room temperature and incubated with various primary antibodies overnight at $4{ }^{\circ} \mathrm{C}$. After three TBST washes, the membranes were incubated with HRP-conjugated anti-mouse or anti-rabbit antibody for $2 \mathrm{~h}$ at room temperature. The final immunoreactive products were detected with an enhanced chemiluminescence (ECL) system.

4.2.5. shRNA transfection. The shNur77 (5'-ACAGTCCAGCCATGCTCCT-3 ${ }^{\prime}$ ) transfection was performed using TurboFect Transfection Reagent according to the manufacturer's instructions. As a negative control, a no specific scrambled shctr was used. The cells were then treated with $7 \mathbf{n}, 7 \mathbf{s}$ and $7 \mathbf{w}$ for $24 \mathrm{~h}$ respectively.

4.2.6. Statistical analysis. The data were expressed as mean $\pm \mathrm{SD}$. Each assay was repeated in triplicate in three independent experiments. Statistical significance of differences between groups was analysed by using Student's $t$-test or analysis of variance. $P<0.05$ was considered significant.

\subsection{Molecular docking}

4.3.1. Ligand and protein preparation. The 3-D structure of 7s was drawn using Gauss view 5.0 and was optimized with
Gaussian 09 package ${ }^{40}$ at the B3LYP/6-31G (d) level to serve as the docking ligand. The X-ray crystal structure of the Nur77 was downloaded from the protein Data Bank (PDB ID: 4RE8). All of the water molecules and other subunits (GOL, $3 \mathrm{MJ}$ ) were then removed, missing side chains were filled and hydrogen atoms were added, using the Schrödinger 2016-1 software (LLC, New York, NY, USA, 2016). The resulting hydrogen-Nur77 was used as the target receptor for molecular docking.

4.3.2. The docking experiments. Molecular docking was carried out using the Glide programme (Small-Molecule Drug Discovery Suite 2016-1: Glide, version 6.6, Schrödinger, LLC, $\mathrm{NY}, 2016$.) in the standard precision (SP) mode to investigate the mechanism of interaction between the compound $7 \mathbf{s}$ and protein Nur77. The binding site of native ligand 3 MJ was chosen for docking site. Throughout the docking process, the protein Nur77 was held rigid; only the torsional bonds of $7 \mathbf{s}$ were permitted to be free. Default values were used for all the parameters during docking. The docking results presented here were analysed by using PyMOL software ${ }^{\mathbf{4 1}}$ and Maestro, version $10.1 .^{42}$

\section{Conflicts of interest}

There are no conflicts to declare.

\section{Acknowledgements}

This work was supported by the National Natural Science Foundation of China (No. 81773600, 81302652, 31471273, 41376172 and 31461163002), the Project of South Center for Marine Research (No. 14GYY023NF23). This research was also financially supported by Fujian Science and Technology project (No. 2014N5012). We also thank the College of Pharmaceutical Sciences, Xiamen University and the Department of Chemistry, College of Chemistry and Chemical Engineering, Xiamen University for providing us with the Shrodinger 2015-1 software and Gaussian 09 software.

\section{Notes and references}

1 A. Chawla, J. J. Repa, R. M. Evans and D. J. Mangelsdorf, Science, 2001, 294, 1866-1870.

2 Z. Xia, X. Cao, E. Rico-Bautista, J. Yu, L. Chen, J. Chen, A. Bobkov, D. A. Wolf, X.-K. Zhang and M. I. Dawson, MedChemComm, 2013, 4, 332-339.

3 Q. Wu, S. Liu, X. F. Ye, Z. W. Huang and W. J. Su, Carcinogenesis, 2002, 23, 1583-1592.

4 S. O. Lee, X. Li, S. Khan and S. Safe, Expert Opin. Ther. Targets, 2011, 15, 195-206.

5 M. A. Maxwell and G. Muscat, Nucl. Recept. Signaling, 2006, 4, e002.

6 H. M. Mohan, C. M. Aherne, A. C. Rogers, A. W. Baird, D. C. Winter and E. P. Murphy, Clin. Cancer Res., 2012, 18, 3223-3228.

7 U. Moll, N. Marchenko and X. Zhang, Oncogene, 2006, 25, 4725-4743. 
8 L. De Léséleuc and F. Denis, Cell Death Differ., 2006, 13, $293-$ 300.

9 F. Weih, R. P. Ryseck, L. Chen and R. Bravo, Proc. Natl. Acad. Sci. U. S. A., 1996, 93, 5533-5538.

10 Y. Li, B. Lin, A. Agadir, R. Liu, M. I. Dawson, J. C. Reed, J. A. Fontana, F. Bost, P. D. Hobbs and Y. Zheng, Mol. Cell. Biol., 1998, 18, 4719-4731.

11 H. Uemura and C. Chang, Endocrinology, 1998, 139, 23292334.

12 Y. Y. Zhan, J. P. He, H. Z. Chen, W. J. Wang and J. C. Cai, Cancer Lett., 2013, 329, 37-44.

13 S. O. Lee, T. Andey, U. H. Jin, K. Kim, M. Singh and S. Safe, Oncogene, 2012, 31, 3265-3276.

14 H. Wu, Y. Lin, W. Li, Z. Sun, W. Gao, H. Zhang, L. Xie, F. Jiang, B. Qin and T. Yan, FASEB J., 2011, 25, 192-205.

15 S. To, W. Zeng, J. Zeng and A. Wong, Br. J. Cancer, 2014, 110, 935-945.

16 S. O. Lee, M. Abdelrahim, K. Yoon, S. Chintharlapalli, S. Papineni, K. Kim, H. Wang and S. Safe, Cancer Res., 2010, 70, 6824-6836.

17 J. Liu, W. Zhou, S. S. Li, Z. Sun, B. Lin, Y. Y. Lang, J. Y. He, X. Cao, T. Yan and L. Wang, Cancer Res., 2008, 68, 88718880 .

18 S. D. Cho, S. O. Lee, S. Chintharlapalli, M. Abdelrahim, S. Khan, K. Yoon, A. M. Kamat and S. Safe, Mol. Pharmacol., 2010, 77, 396-404.

19 T. Sibayama-Imazu, Y. Fujisawa, Y. Masuda, T. Aiuchi, S. Nakajo, H. Itabe and K. Nakaya, J. Cancer Res. Clin. Oncol., 2008, 134, 803-812.

20 K. Yoon, S. O. Lee, S. D. Cho, K. Kim, S. Khan and S. Safe, Carcinogenesis, 2011, 32, 836-842.

21 H. Z. Chen, Q. F. Liu, L. Li, W. J. Wang, L. M. Yao, M. Yang, B. Liu, W. Chen, Y. Y. Zhan, M. Q. Zhang, J. C. Cai, Z. H. Zheng, S. C. Lin, B. A. Li and Q. Wu, Gut, 2012, 67, 714-724.

22 S. Zhe, X. H. Cao, M. M. Jiang, Y. K. Qiu, H. Zhou, L. Q. Chen, B. Qin, H. Wu, F. Q. Jiang, J. B. Chen, J. Liu, Y. Dai, H. F. Chen, Q. Y. Hu, Z. Wu, J. Z. Zeng, X. S. Yao and X. K. Zhang, Oncogene, 2012, 31(21), 2653-2667.

23 L. Hao, J. Luan, D. Zhang, C. Li, H. Guo, L. Qi, X. Liu, T. Li and Q. Zhang, Colloids Surf., B, 2014, 117, 258-266.

24 B. Liang, X. Song, G. Liu, R. Li, J. Xie, L. Xiao, M. Du, Q. Zhang, X. Xu and X. Gan, Exp. Cell Res., 2007, 313, 2833-2844.

25 P. C. Lin, Y. L. Chen, S. C. Chiu, Y. L. Yu, S. P. Chen, M. H. Chien, K. Y. Chen, W. L. Chang, S. Z. Lin and T. W. Chiou, J. Neurochem., 2008, 106, 1017-1026.
26 S. Liu, H. Yu, S. M. Kumar, J. S. Martin, Z. Bing, W. Sheng, M. Bosenberg and X. Xu, Cancer Biol. Ther., 2011, 12, 10051014.

27 M. Z. Zhang, N. Mulholland, D. Beattie, D. Irwin, Y. C. Gu, Q. Chen, G. F. Yang and J. Clough, Eur. J. Med. Chem., 2013, 63, 22-32.

28 M. Z. Zhang, Q. Chen and G. F. Yang, Eur. J. Med. Chem., 2015, 89, 421-441.

29 R. Álvarez, P. Puebla, J. F. Díaz, A. C. Bento, R. García-Navas, J. de la Iglesia-Vicente, F. Mollinedo, J. M. Andreu, M. Medarde and R. Peláez, J. Med. Chem., 2013, 56, 28132827.

30 M. Nguyen, R. C. Marcellus, A. Roulston, M. Watson, L. Serfass, S. R. M. Madiraju, D. Goulet, J. Viallet, L. Belec, X. Billot, S. Acoca, E. Purisima, A. Wiegmans, L. Cluse, R. W. Johnstone, P. Beauparlant and G. C. Shore, Proc. Natl. Acad. Sci. U. S. A., 2007, 104, 19512-19517.

31 O. I. Parisi, C. Morelli, L. Scrivano, M. S. Sinicripi, M. G. Cesario, S. Candamano, F. Puoci and D. Sisci, RSC Adv., 2015, 5, 65308-65315.

32 H. Y. Hu, X. D. Yu, F. Wang, C. R. Lin, J. Z. Zeng, Y. K. Qiu, M. J. Fang and Z. Wu, Molecules, 2016, 21, 530.

33 T. H. Maugh, Science, 1979, 206, 1058-1060.

34 T. A. Blanpied, R. J. Clarke and J. W. Johnson, J. Neurosci., 2005, 25, 3312-3322.

35 M. W. Robinson, J. H. Overmeyer, A. M. Young, P. W. Erhardt and W. A. Maltese, J. Med. Chem., 2012, 55, 1940-1956.

36 L. L. Yang, G. B. Li, S. Ma, C. Zou, S. Zhou, Q. Z. Sun, C. Cheng, X. Chen, L. J. Wang, S. Feng, L. L. Li and S. Y. Yang, J. Med. Chem., 2013, 56, 1641-1655.

37 J. Yao, J. Chen, Z. He, W. Sun and W. Xu, Design, synthesis and biological activities of thiourea containing sorafenib analogs as antitumor agents, Bioorg. Med. Chem., 2012, 20(9), 2923-2929.

38 Y. C. Duan, Y. C. Zheng, X. C. Li, M. M. Wang, X. W. Ye, Y. Y. Guan, G. Z. Liu, J. X. Zheng and H. M. Liu, Eur. J. Med. Chem., 2013, 64, 99-110.

39 M. Hassan, H. Watari, A. AbuAlmaaty, Y. Ohba and N. Sakuragi, BioMed Res. Int., 2014, 1-23.

40 Y. Han, X. Cao, B. Lin, F. Lin, S. Kolluri, J. Stebbins, J. Reed, M. Dawson and X. Zhang, Oncogene, 2006, 25, 2974-2986.

41 W. L. DeLano, The PyMOL Molecular Grapics System, 2002. 42 Schrödinger Release 2016-1: Maestro, Schrödinger, LLC, New York, NY, 2016. 